\title{
PRELIMTNARY DATA REPORT
}

\section{PRESSURE TRANSDUCERS EXPERIMENT NO. 23/N506,}

\section{IRRADIATED AT PLUM BROOK REACTOR FACILITY,}

PBRF CYCLE 22P (PB NO. 8W). 35

Prepared By:

D. G. Freas
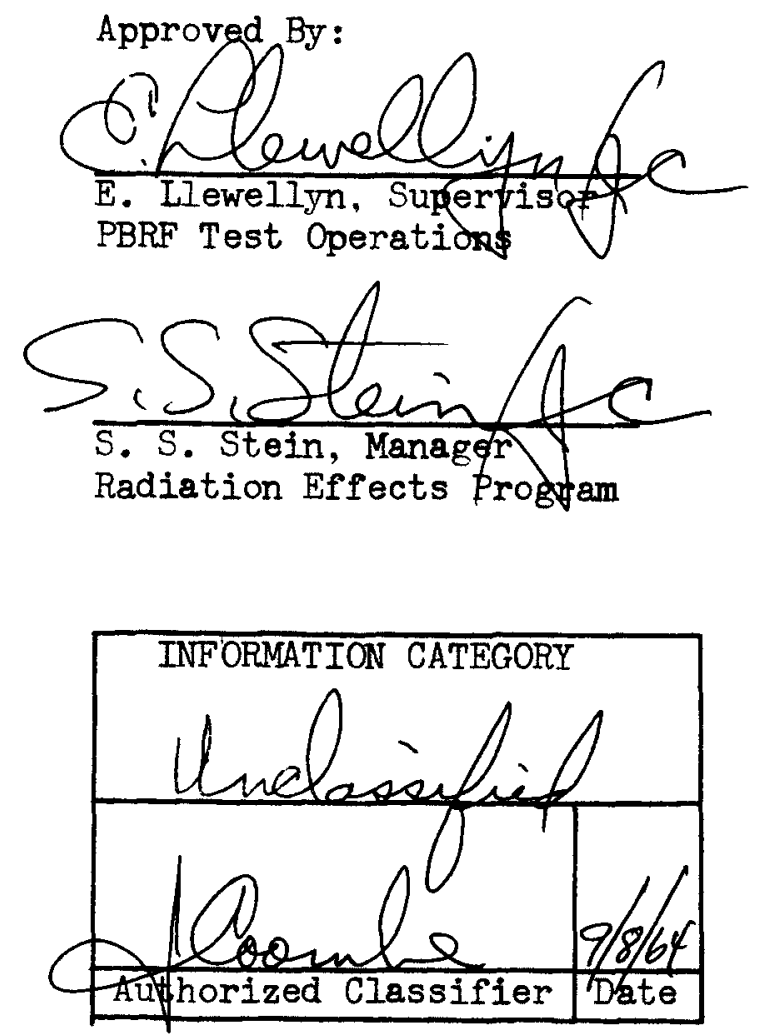

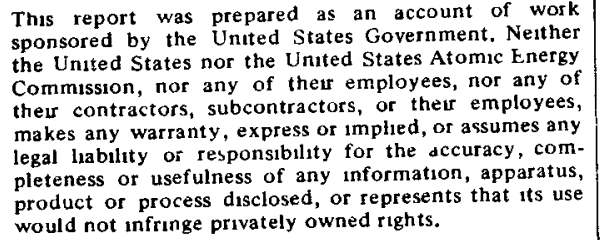

would not infringe privately owned rights.

Westinghouse Electric Corporation Astronuclear Laboratory

Pittsburgh 36, Pennsylvania 


\section{DISCLAIMER}

This report was prepared as an account of work sponsored by an agency of the United States Government. Neither the United States Government nor any agency Thereof, nor any of their employees, makes any warranty, express or implied, or assumes any legal liability or responsibility for the accuracy, completeness, or usefulness of any information, apparatus, product, or process disclosed, or represents that its use would not infringe privately owned rights. Reference herein to any specific commercial product, process, or service by trade name, trademark, manufacturer, or otherwise does not necessarily constitute or imply its endorsement, recommendation, or favoring by the United States Government or any agency thereof. The views and opinions of authors expressed herein do not necessarily state or reflect those of the United States Government or any agency thereof. 


\section{DISCLAIMER}

Portions of this document may be illegible in electronic image products. Images are produced from the best available original document. 
TABLE OF CONTENTS

\begin{tabular}{|c|c|c|}
\hline 1.0 & INTRODUCTION & 1 \\
\hline 2.0 & TEST HISTORY & 1 \\
\hline 3.0 & DESCRIPTION OF TEST & 3 \\
\hline & 3.1 Description of Test Specimen & 3 \\
\hline & 3.2 Description of Test Fixture & 3 \\
\hline & 3.3 Test Procedure & 7 \\
\hline & 3.4 Test Results & 9 \\
\hline & 3.5 Raw Data & 14 \\
\hline 4.0 & REFERENCES & 36 \\
\hline
\end{tabular}




\section{LIST OF ILLUSTRATIONS}

Figure

Title

$\underline{\text { Page }}$

1

Reactor Power Profile, PBR Cycle 22P

2

Side View of the Aluminum Cage of Pressure

4

Transducer Experiment 23/W506

End View of the Aluminum Cage of Pressure

Transducer Experiment 23/W506

4

Design of the Test Fixture for Experiment 23/W506

Pneumatic System Used to Regulate the Gas Pressure in Experiment 23/W506

Transducer No. 69953

7

Coil Resistance vs. Reactor Power -

Transducer No. 69952

8

Coil Resistance vs. Reactor Power Transducer No. 70639

9

Coil Resistance vs. Reactor Power Transducer No. 69955 
(w) Stronuclear $_{\text {str. }}$

WANI-TME-916

LIST OF TABIES

Table

Title

Page

1 Variable Reluctance Pressure Transducers

Irradiated in Experiment 23/W506

2

Data Acquisition Equipment for Experiment 23/W506

3

Output Voltages - Model 54727 Differential

Transducer No. 69953

$4 \quad$ Output Voltages - Model 54727 Differential

Transducer No. 69952

Transducer No. 70639

6

Output Voltages - Model 54726 Absolute

Transducer No。 69955

Co1l and Insulation Resistances - Model 54727

Differential Transducer No.69953

8

Coil and Insulation Resistances - Model 54727

Coil and Insulation Resistances - Model 54726

Absolute Transducer No. 70639

Coil and Insulation Resistances - Model 54726

34

Absolute Transducer No. 69955 
(w)

stronuclear

WANI-TME-916

\subsection{INTRODUCTION}

Description of the preliminary results of experiment 23/W506, irradiated during PBR Cycle 22P. is presented in this report。 In this experiment, two Wianko variable reluctance absolute pressure transducers, Model No. 54726, and two Wianko variable reluctance differential pressure transducers, Model No. 54727 were dynamically tested during irradiation in the PBR HT-I facility on July 29 and 30, 1964. Experiment 23/N506 was designed to evaluate the performance of the Wianko pressure transducers under dose rate conditions approaching and exceeding those to be experienced in both NRX-A2 and NRX-A3 applications. Since these transducers in application are to be utilized in fields of different radiation levels, this irradiation experiment was exposed to various radiation dose rates. In an effort to obtain comparable data, the pressure transducers of this experiment were pressure cycled before, during, and after irradiation.

Design and hazards information for the W-2 loop is described in WANL-TNR-119(1), and for this experiment, in WANL-REP-2012 $(2)$. Final test specifications for this experiment are described in WANI-TME-800(3)。

\subsection{TEST HISTORY}

Irradiation of pressure transducer experiment 23/W506 was initiated at about 2144 hours on July 29, 1964 in the PIum Brook Reactor and was completed at approximately 1622 hours on July 30, 1964. In order that various radiation dose rates might be experienced, the reactor power was increased to levels of $1 \mathrm{MW}, 5 \mathrm{MW}$, and increasing $5 \mathrm{MW}$ increments up to $40 \mathrm{MW}$. Each of these power levels was held for approximately two hours to permit temperature stabilization. Two complete pressure cycles of data were taken during each of these periods. Due to indications of malfunction in two of the transducers, one absolute and one differential type, this irradiation experiment was terminated at the conclusion of the $40 \mathrm{MW}$ period. A total exposure of about $363 \mathrm{MN}$-hours was accumulated during irradiation. Figure 1 illustrates the reactor power profile during this experiment as indicated by the PBRF water power computer. During the above described operating conditions, the outer surface of the pressure transducers experienced temperatures ranging from $85^{\circ} \mathrm{F}$ to $125^{\circ} \mathrm{F}$ and was exposed to an average water pressure of 132 psig. 


\section{(3) $\left.\right|_{\text {|stroncterar }}$ WANL-TME-916}

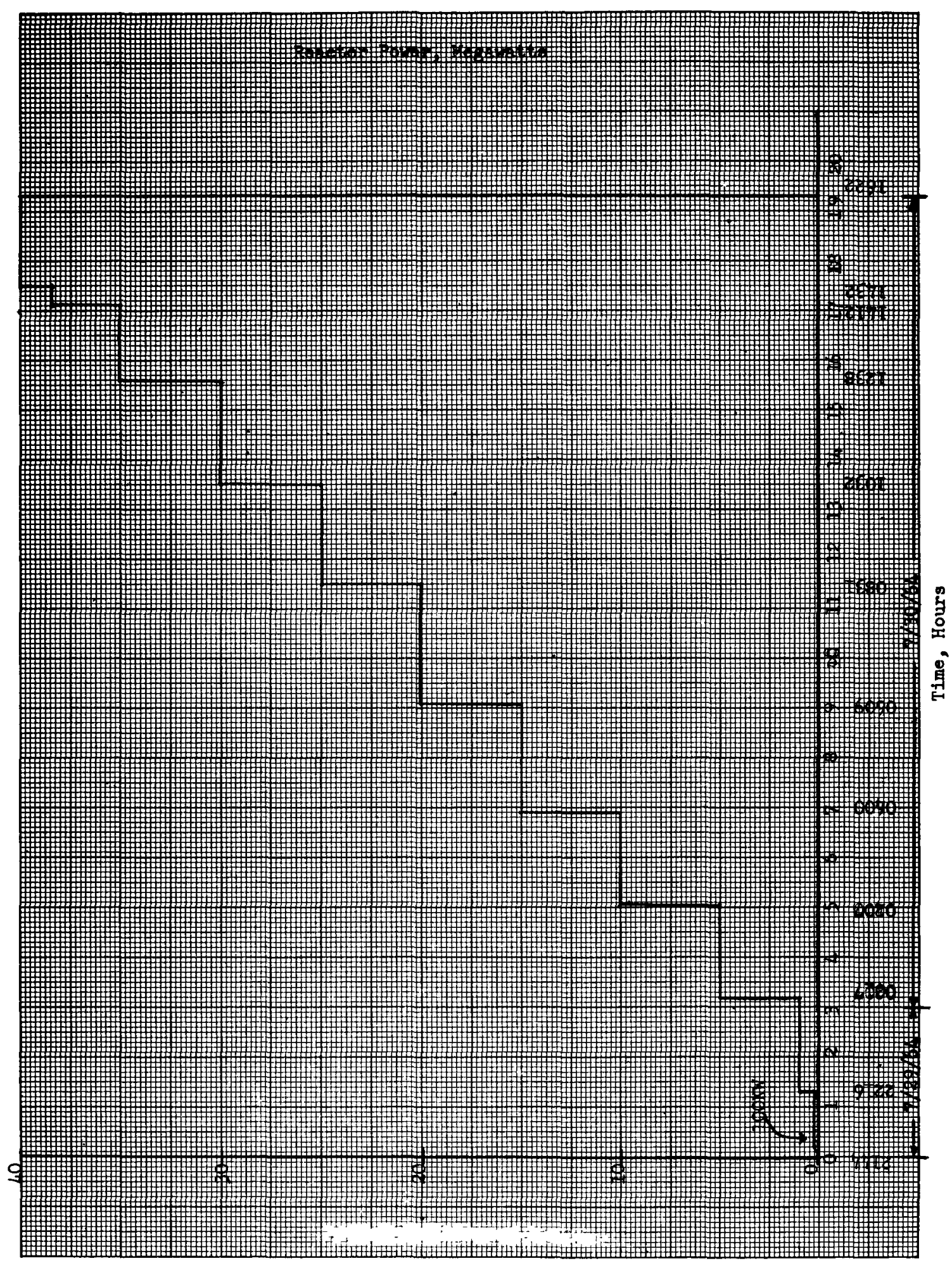

Figure 1. Reactor Power Profile PBR Cycle 22P 


\subsection{DESCRIPTION OF TEST}

\subsection{Description of Test Specimens}

The four pressure transducers irradiated in this experiment are listed in Table 1. These transducers were clamped to the inside edge of the test fixture cage at $90^{\circ}$ intervals. During irradiation, the transducers were directly actuated from a helium gas supply incorporated in the system.

\section{Table 1}

Variable Reluctance Pressure Transducers Irradiated in Experiment 23/W506

\begin{tabular}{|c|c|c|c|c|c|}
\hline Quantity & Manufacturers & Model No. & Type & Range & $\begin{array}{c}\text { Instrumentation } \\
\text { Data Book } \\
\text { Code Number } \\
\end{array}$ \\
\hline 2 & Wiancko & 54726 & Absolute & 0 to 800 psia & $\operatorname{Pr}-18$ \\
\hline 2 & Wiancko & 54727 & Differential & 0 to 150 psid & DPr-16 \\
\hline
\end{tabular}

\subsection{Description of Test Fixture}

The test fixture for experiment 23/W506 was designed with an aluminum cage into which four Wiancko pressure transducers were clamped and welded, (Figures 2 and 3.) This cage also contained a manifold and tubing system which permitted transfer of gas from the pressurized helium supply to each transducer (Figure 4). During irradiation the applied gas pressure to the transducers was manually regulated from a pneumatic system positioned near the helium bottle supply. The cage of the test fixture was enclosed with an aluminum shroud to direct flow of coolant water and the entire fixture was attached to the unitrace holder as described in WANL-TNR-119(I).

Four stainless steel sheathed copper-constantan thermocouples were pressure fitted between each of the pressure transducers and the aluminum cage. In this manner the outer surface temperature of each transducer was continually monitored during irradiation. The radiation exposure of each transducer was monitored by a dosimeter package mounted on the test fixture near to each transducer. Each dosimeter package contained aluminumcobalt wires, bare and cadmium covered for thermal and epi-thermal flux measurements, and sulfur for fast flux measurements. One 0.090-inch diameter. 13 foot long, stainless steel-sheathed cable with MgO insulation was provided from each transducer to the conax fittings in the back plate 


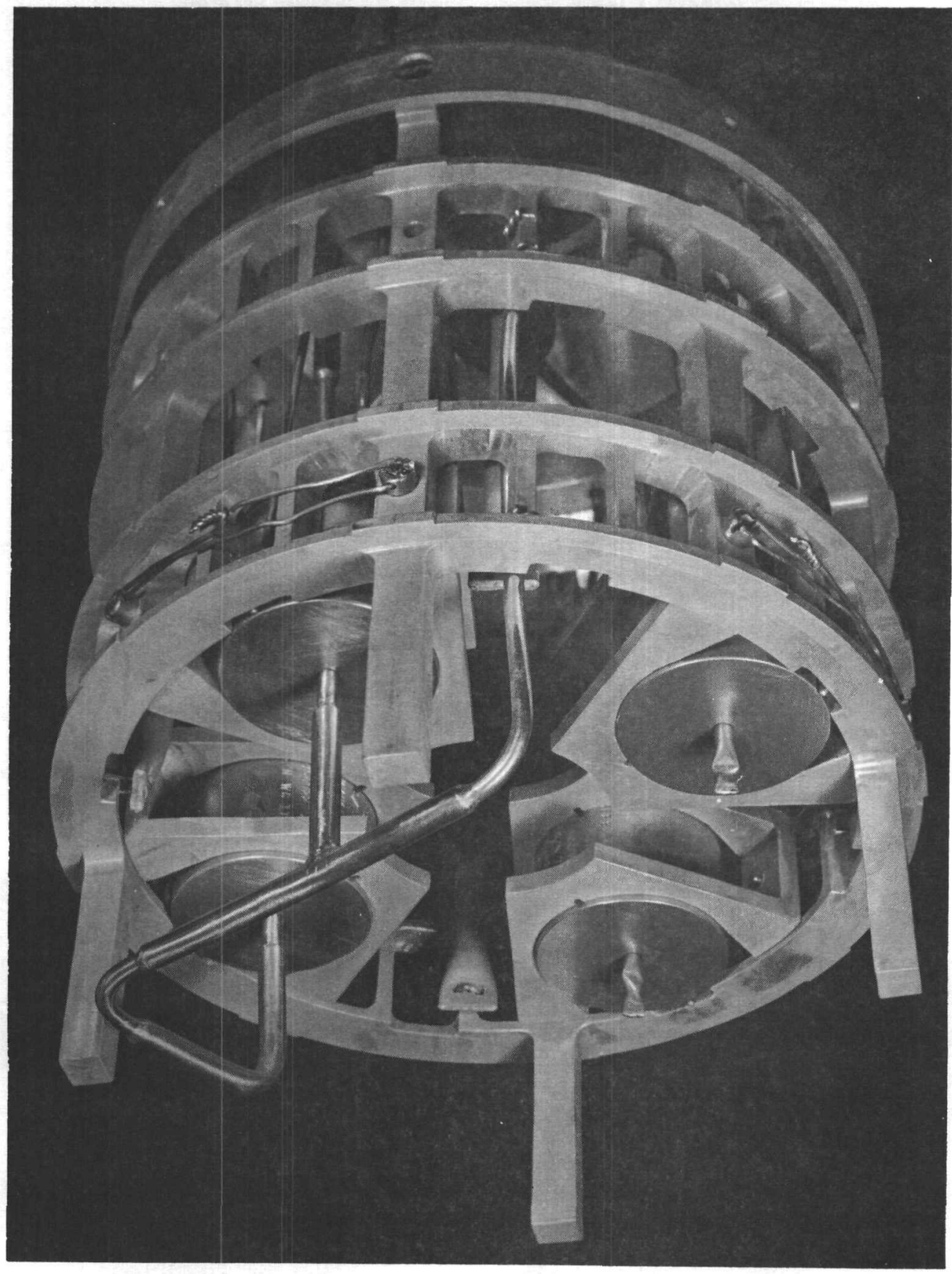

Figure 2. Side View of the Aluminum Cage of Pressure Transducer Experiment 23/W506 


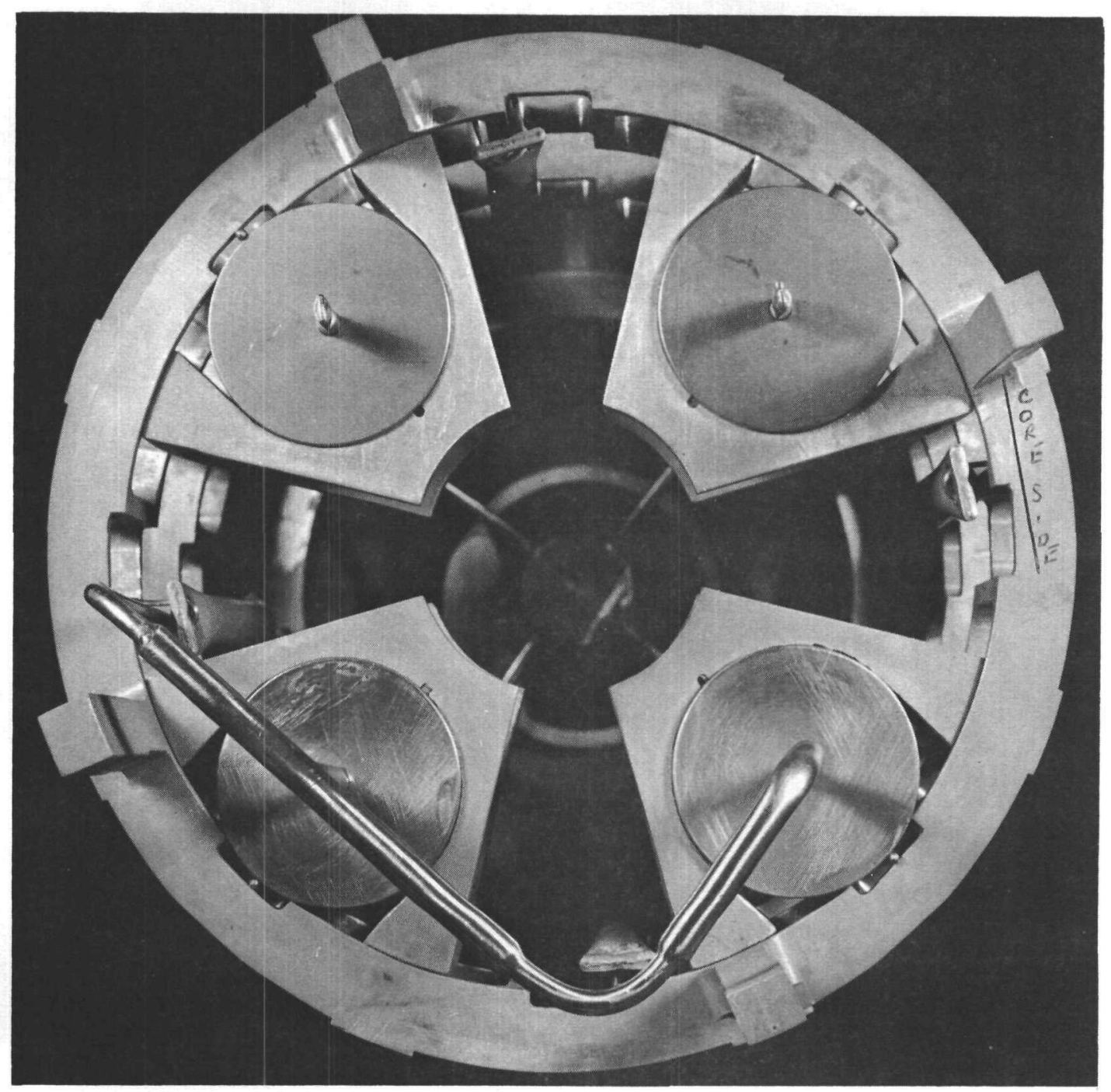

Figure 3. End View of the Aluminum Cage of Pressure Transducer Experiment 23/W506 

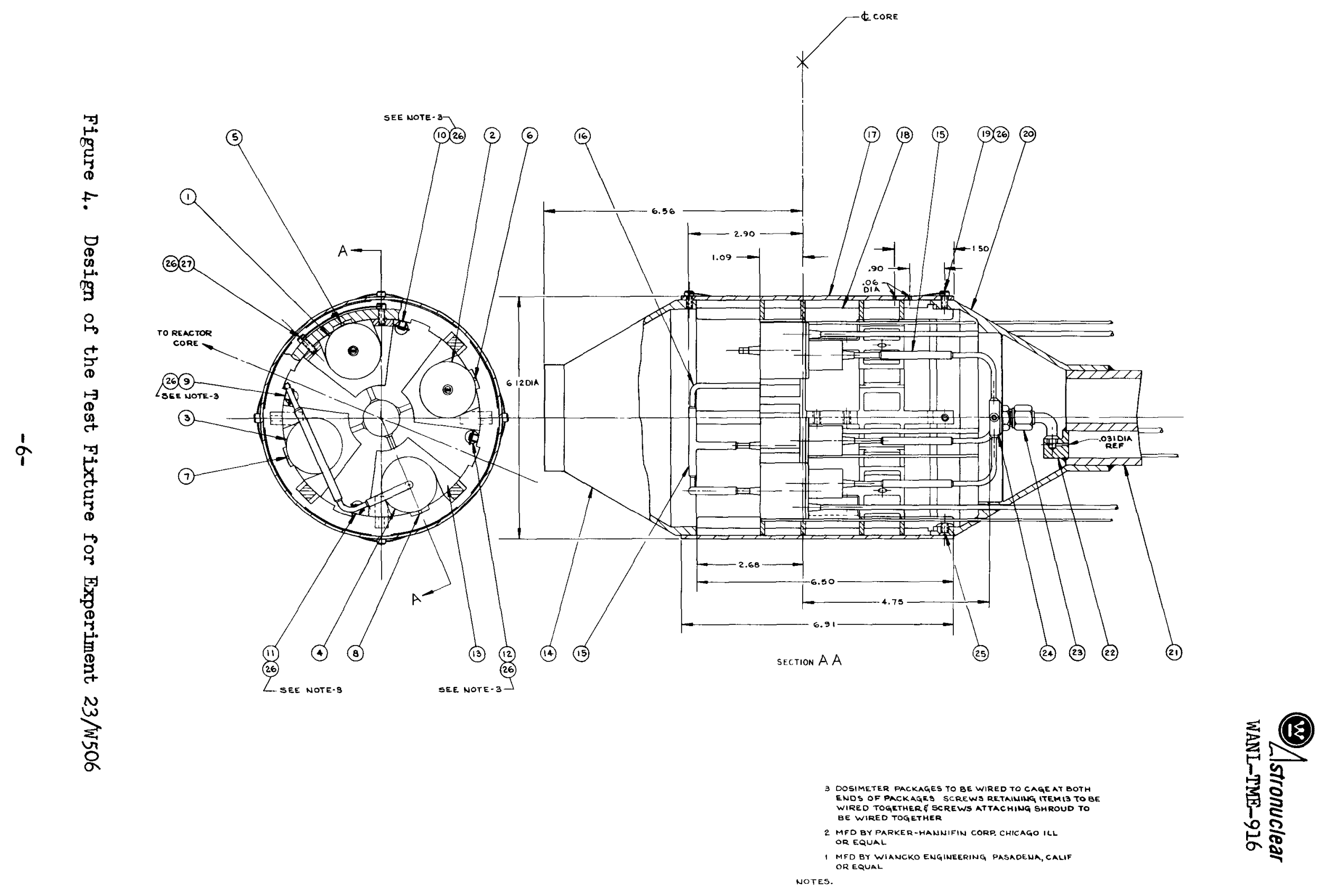
of the sample holder to provide read-out capabilities. Extension wires from the test holder backplate to the read-out instrumentation were enclosed in Tygon tubing to prevent exposure to moisture.

\subsection{Test Procedure}

To determine the effects of irradiation on the Niancko pressure transducers of this experiment, a helium gas actuating system and data read-out equipment were required. A diagram of the He gas supply and reference vent system for this experiment is shown in $F$ igure 5. The data read-out equipment for this experiment, included in Table 2, was mounted to an instrument control panel from which the test procedures were regulated. Since evaluation of the Wiancko pressure transducers will be performed from resistance measurements of the transducer electric circuit and voltage output levels during irradiation, the instrumentation was designed to provide these capabilities.

Table 2

Data Acquisition Equipment for Experiment 23/W506

1. Two digital voltmeters, Kintel, Model 473 A。

2. Two Crescent Demodulators, Model 9105 (one spare)。

3. One Hewlett-Packard Oscillator, Model 650A.

4. One McIntosh Amplifier, Model MI75.

5. One $A C$ to $D C$ converter.

6. One Megohmmeter, General Radio.

7. One Wheatstone Bridge.

8. One AC Voltage Regulator.

9. Two Heise Pressure Gages, 0-50 psi and 0-200 psi.

During irradiation a gas pressure of 100 psig was continually mairitained on the pressure transducers except during the periods of data acquisition. Prior to each data acquisition operation, the read-out instrumentation was standardized according to procedure 4.2 of WANI-TNR-118(4) to insure the measurement of true values. After standardization operations were completed, the voltage output of each transducer with a 100 psig gas pressure applied was measured and recorded. The gas pressure was then released to 0 psig and the voltage outputs again measured. This operation 


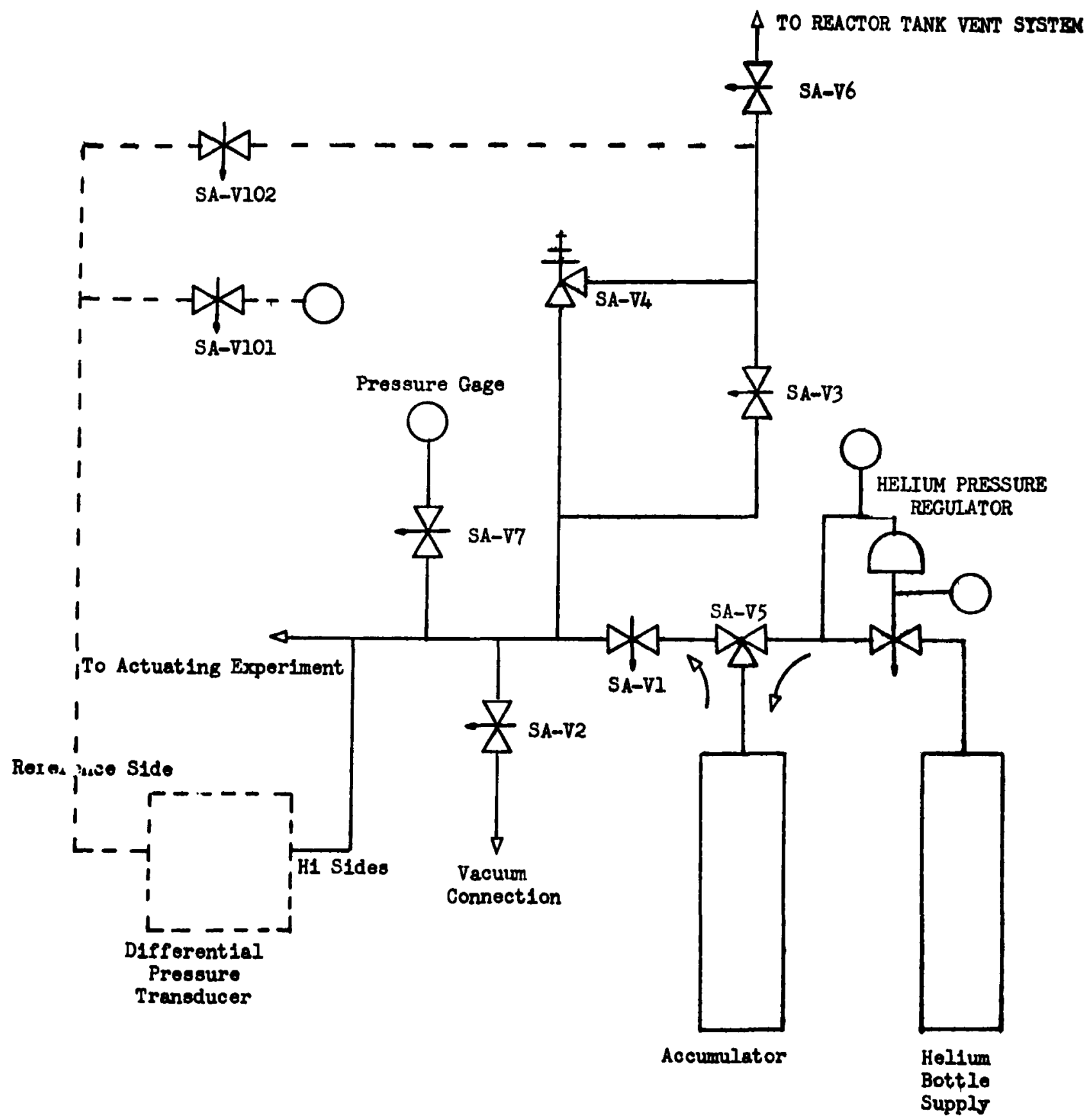

Figure 5. Pneumatic System Used to Regulate the Gas Pressure in Experiment 23/W506 
was repeated at 30 psig increments up to 150 psig and back to 0 psig. At the completion of these operations the transducer gas pressure was again regulated to $100 \mathrm{psig}$ and maintained throughout irradiation. The electrical resistance across the core of each transducer was measured to indicate temperature changes resulting from irradiation. The insulation resistance of each transducer was also measured to indicate its resistance to radiation damage. The above procedure describes one complete pressure cycle of data acquisition for the pressure transducers. These operations were repeated at the beginning and end of each reactor power level period to insure that temperature stabilization had occurred. Complete data cycles were taken just prior to irradiation and immediately following irradiation to permit data comparison for the study of radiation induced changes and recovery characteristics.

\subsection{Test Results}

As mentioned earlier in this report, the irradiation of this experiment was conducted at $5 \mathrm{MW}$ increments up to $40 \mathrm{MW}$ at which point the experiment was terminated. Termination was requested as the result of malfunction indicated by the output voltages of two of the transducers. A review of the data in Tables 3 through IC shows the following results:

1. Pressure transducer number 69953 (variable reluctance differential type) experienced an increase in the DC output voltage of approximately 0.11 volts with increased reactor power level to $40 \mathrm{MN}$. This increase was fairly constant over the 150 psig pressure range applied to the transducer. At each reactor power level an approximate 1.0 volt increase was experienced with each $30 \mathrm{psig}$ increase or about 0.033 volts per pound. On this basis the 0.11 volt increase of the DC output experienced during irradiation would be equivalent to an approximate 3 psi or $2 \%$ increase in pressure for each of the 30 psig increments. The coil resistance of this transducer increased at an average rate of 0.4 ohms per MW and upon reactor shutdown exhibited a total recovery behavior. (Figure 6.) It is therefore believed that resistance increases during irradiation were due only to coil temperature increases. The insulation of this transducer appeared to have experienced a decrease in resistance with increased reactor power (although somewhat erratic up to $15 \mathrm{MW}$ ); however, total recovery was experienced with react or shutdown. This transducer was located in the test fixture at a position farthest from the reactor core and should therefore have experienced a minimum radiation exposure.

2. Pressure transducer number 69952 (variable reluctance differential type) experienced a DC voltage output increase of only about 0.034 volts with increased reactor power level up to $20 \mathrm{MW}$. This increase was constant over the $150 \mathrm{psig}$ pressure range applied to the transducer. At each power level up to $20 \mathrm{MW}$ an approximate $l_{.} .1$ volt increase was experienced with each 30 psig increase of about 0.036 volts per pound. On this 


\section{(3)/stroncterer WANL-TME-916}

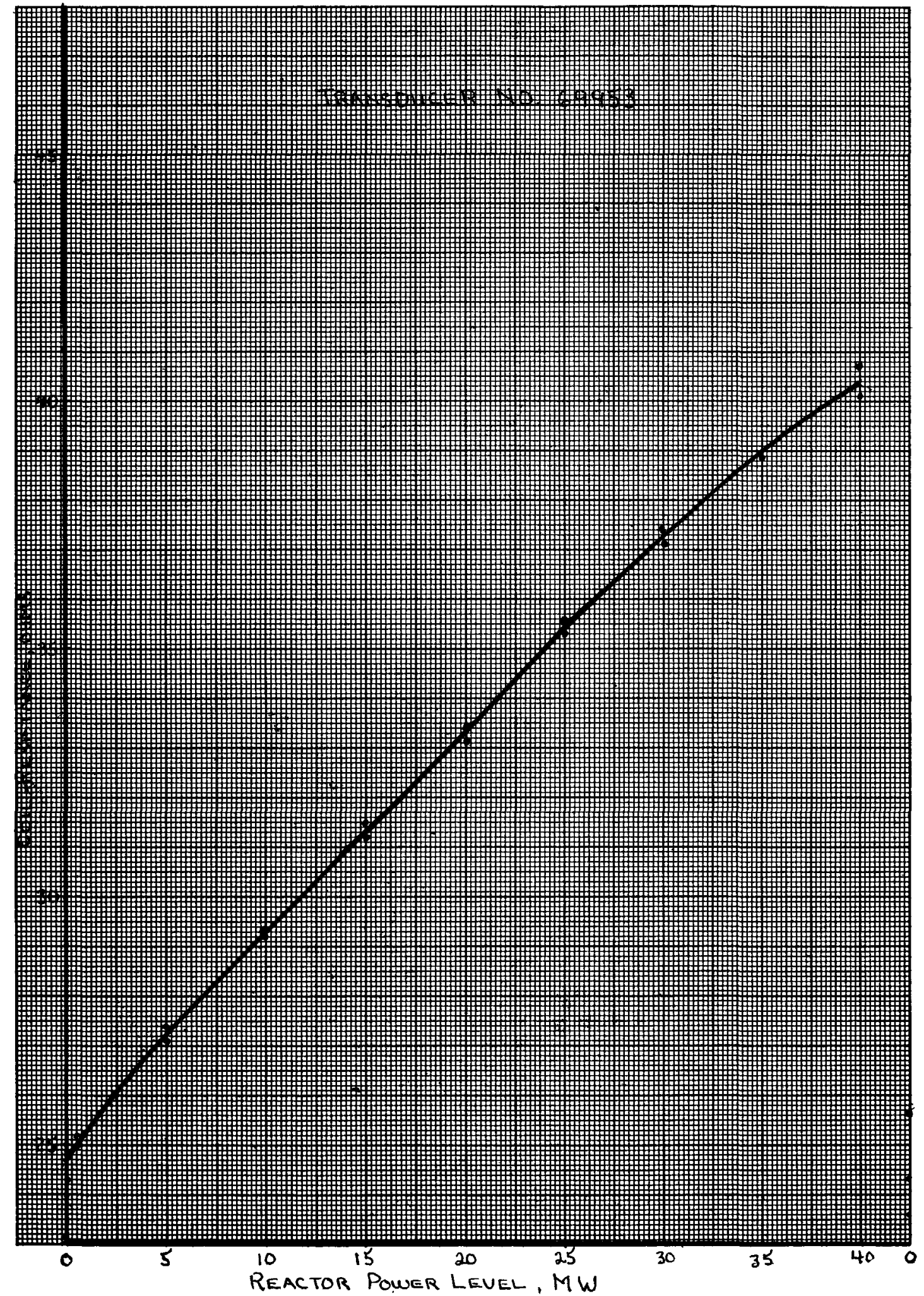

Figure 6. Coil Resistance vs. Reactor Power - Transducer No. 69953 
basis the 0.034 volt increase of the DC output would be equivalent to an approximate 1 psi or less than $1 \%$ increase in pressure for each 30 psig increment during irradiation to $20 \mathrm{MW}$. Upon going to the $25 \mathrm{MW}$ power level the DC voltage output at each 30 psig pressure increment was noted to decrease by about 0.1 volts as compared to the output at $20 \mathrm{MW}$. At $30 \mathrm{MW}$ the DC voltage outputs were noted to increase considerably over those at the $25 \mathrm{MW}$ level. Also the DC voltage changes for each $30 \mathrm{psig}$ increment were non-uniform indicating that the sensitivity of this transducer had become erratic. DC output voltages throughout the remainder of the irradiation were erratic and decreases in the $\mathrm{AC}$ output voltage was noted during the latter period of irradiation. Data obtained after reactor shutdown failed to show any indications of recovery. The coil resistance of this transducer increased fairly uniformly up to $20 \mathrm{MW}$. On going from 20 to $25 \mathrm{MW}$ a slightly greater increase in resistance was experienced than was anticipated under normal behavior. (Figure $7_{\circ}$ ) Upon react or shutdown the coil resistance returned to near normal values for $0 \mathrm{MW}$. The insulation of this transducer experienced a decrease in resistance with increased react or power, however, total recovery was experienced with reactor shutdown. This transducer was located in the test fixture at a position closest to the reactor core and should therefore have experienced a maximum radiation exposure.

3. Pressure transducer number 70639 (variable reluctance absolute type) experienced a decrease in the DC voltage output with increased reactor power up to $20 \mathrm{MW}$. This decrease was not uniform for each additional $5 \mathrm{MW}$ of power. A DC voltage increase for each 30 psig increase in pressure at a given power level was fairly constant indicating that the transducer sensitivity had been maintained. Upon increasing the reactor power from $20 \mathrm{MW}$ to $25 \mathrm{MW}$ an approximate 2.1 volt increase in the DC output was observed for each 30 psig pressure increase. Also the AC voltage output was noted to decrease. Voltage output measurements for this transducer throughout the remainder of the irradiation to $40 \mathrm{MW}$ was considered to be erratic. No indication of recovery was noted after reactor shutdown, thereby suggesting that permanent damage had occurred. The coil resistance of this transducer was noted to increase at a fairly uniform rate up to about $20 \mathrm{MW}$ (Figure 8). From $20 \mathrm{MW}$ to $40 \mathrm{MW}$ the coil resistance became quite erratic and upon reactor shutdown the resistance decreased to values lower than those measured prior to irradiation. The insulation of this transducer experienced a rapid decrease in resistance upon reactor power increase to $5 \mathrm{MW}$ after which further decreases in resistance were less severe. After reactor shutdown the insulation resistance of this transducer was noted to return to pre-irradiation levels. This transducer was located in the test fixture at a position closest to the reactor core and should therefore have experienced a maximum radiation exposure.

4. Pressure transducer number 69955 (variable reluctance absolute type) experienced an initial decrease in the DC output voltage with increased reactor power to $10 \mathrm{MW}$ afterwhich a fairly uniform increase was experienced 


\section{(2): $\left.\right|_{\text {stronuclear }}$ WANI-TME-916}

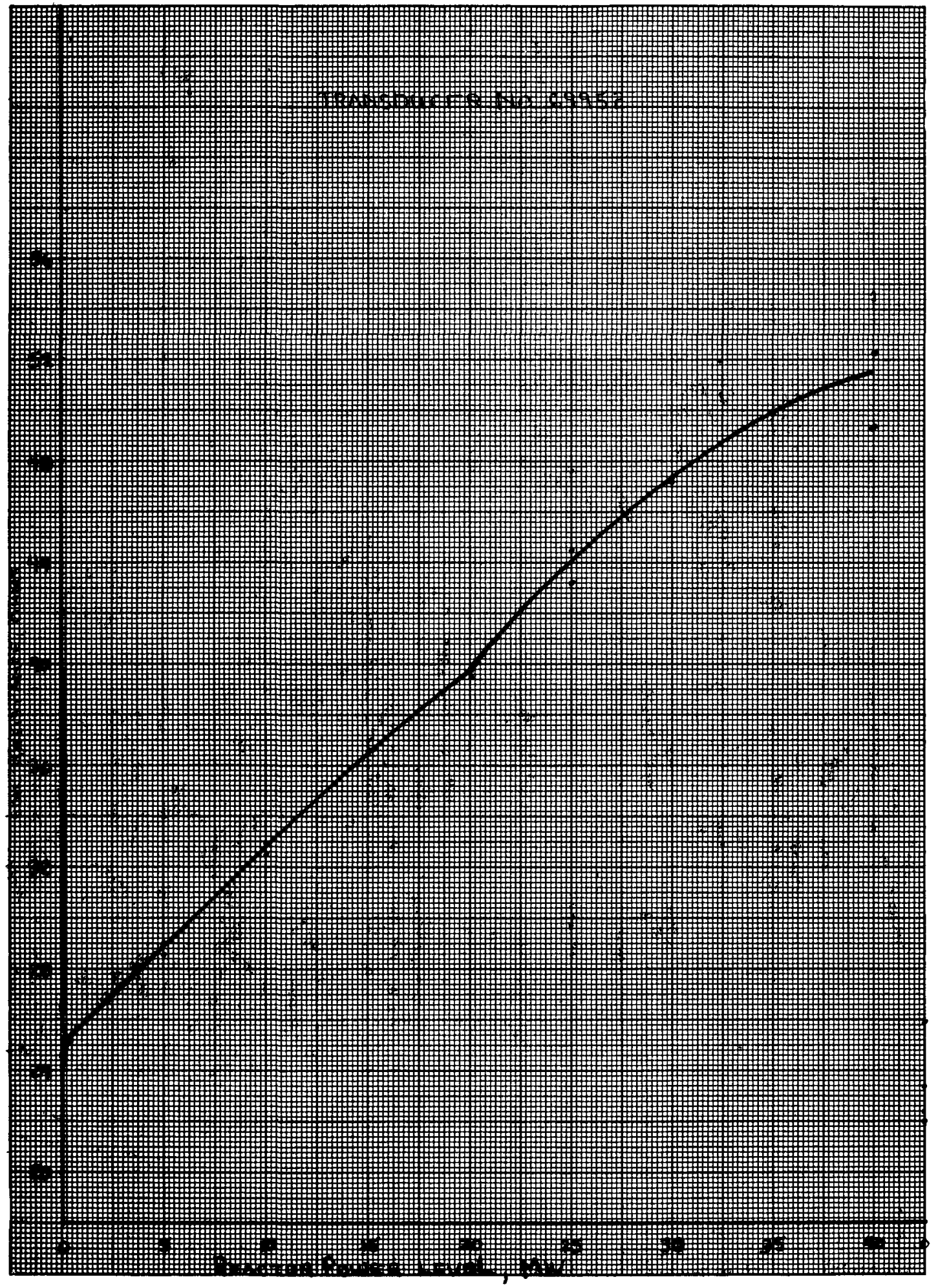

Figure 7. Coil Resistance vs. Reactor Power - Transducer No. 69952 


\section{(2) WANI-TME-916}

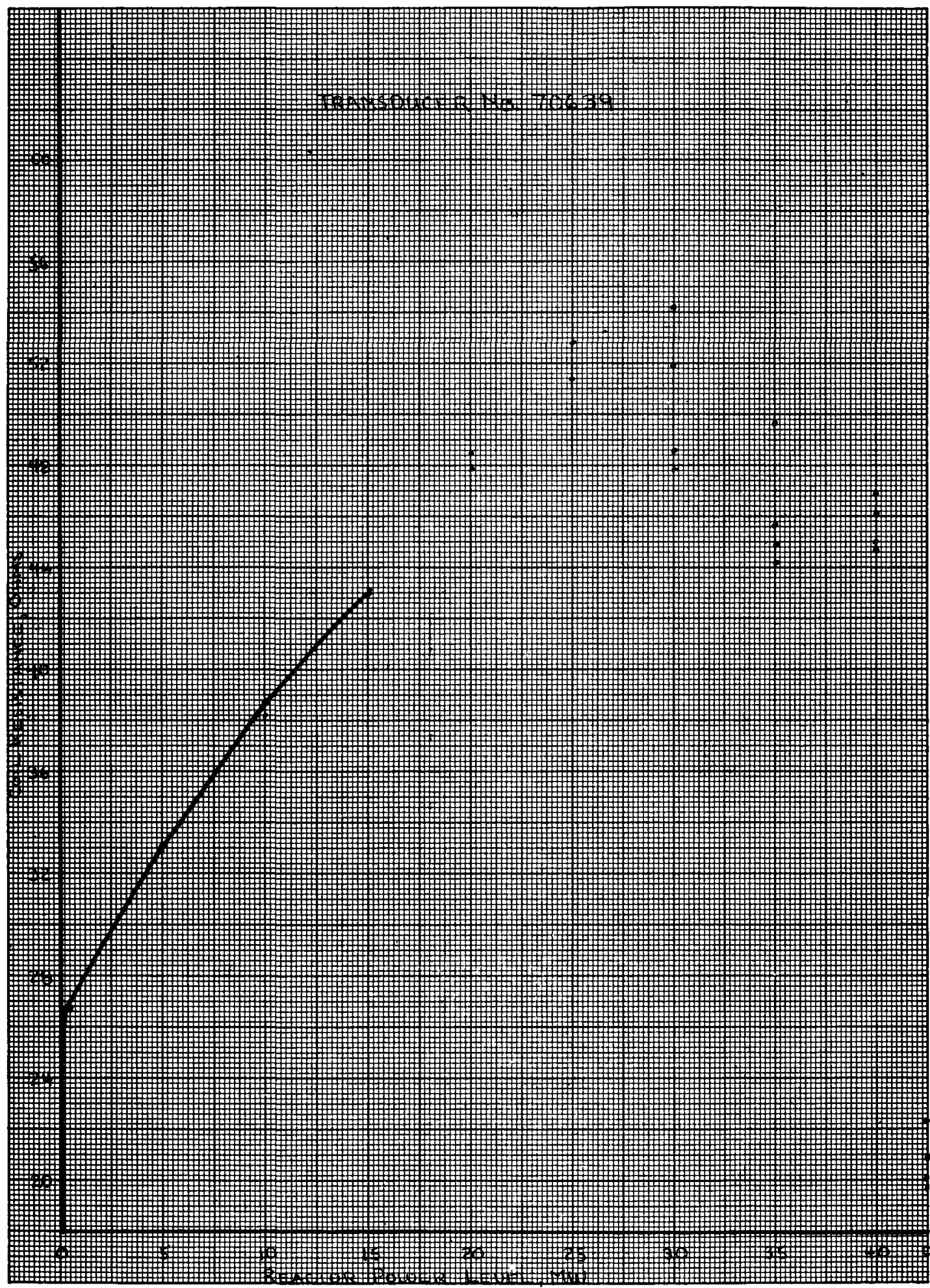

Figure 8. Coil Resistance vs. Reactor Power - Transducer No. 70639 
up to $40 \mathrm{M}$. The overall average increase in the DC output during irradiation was about 0.43 volts. With react or shutdown some decrease in DC voltage output was noted; however, recovery to the pre-irradiation values was not observed. At each reactor power it was noted that the increase in DC voltage output with each 30 psig increase in pressure was fairly uniform indicating that the sensitivity of the transducer had been maintained. The coil resistance of this transducer increased at an average rate of about 0.53 ohms per MW. (Figure 9.) With reactor shutdown, the coil resistance of this transducer returned to pre-irradiation values, thereby suggesting that the increases during irradiation were due to temperature alone. The insulation of this transducer appeared to have a continual decrease in resistance with increased reactor power; however, resistances appeared to return to normal with reactor shutdown. This transducer was located in the test fixture at a position farthest from the reactor core and should therefore have experienced a minimum radiation exposure.

Throughout this irradiation experiment, the temperature of each transducer was continually monitored, along with the inlet and outlet coolant water. Although the transducer temperature deviated somewhat with operation of the primary coolant pumps it was found that the temperature ranged from $85^{\circ} \mathrm{F}$ to $124^{\circ} \mathrm{F}$.

\subsection{Raw Data}

The $A C$ and $D C$ voltage outputs measured prior to irradiation, during irradiation and after reactor shutdown are presented in Tables 3 through 6 along with the time and reactor power. The coil resistances and insulation resistances of each transducer are presented in Tables 7 through 10. 


\section{(:) $/$ stronuclear \\ WANL-TME-916}

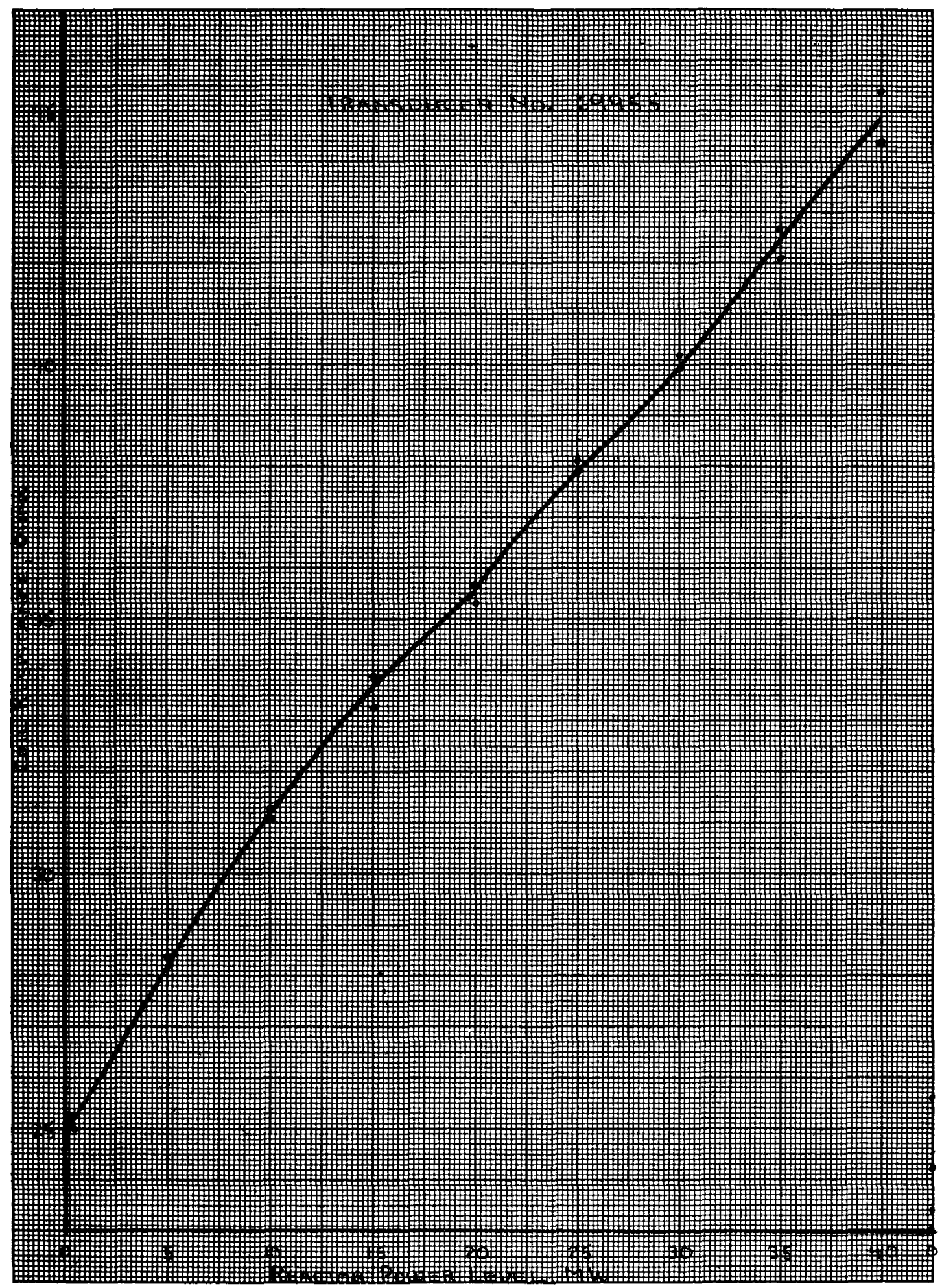

Figure 9. Coil Resistance vs. Reactor Power - Transducer No. 69955 


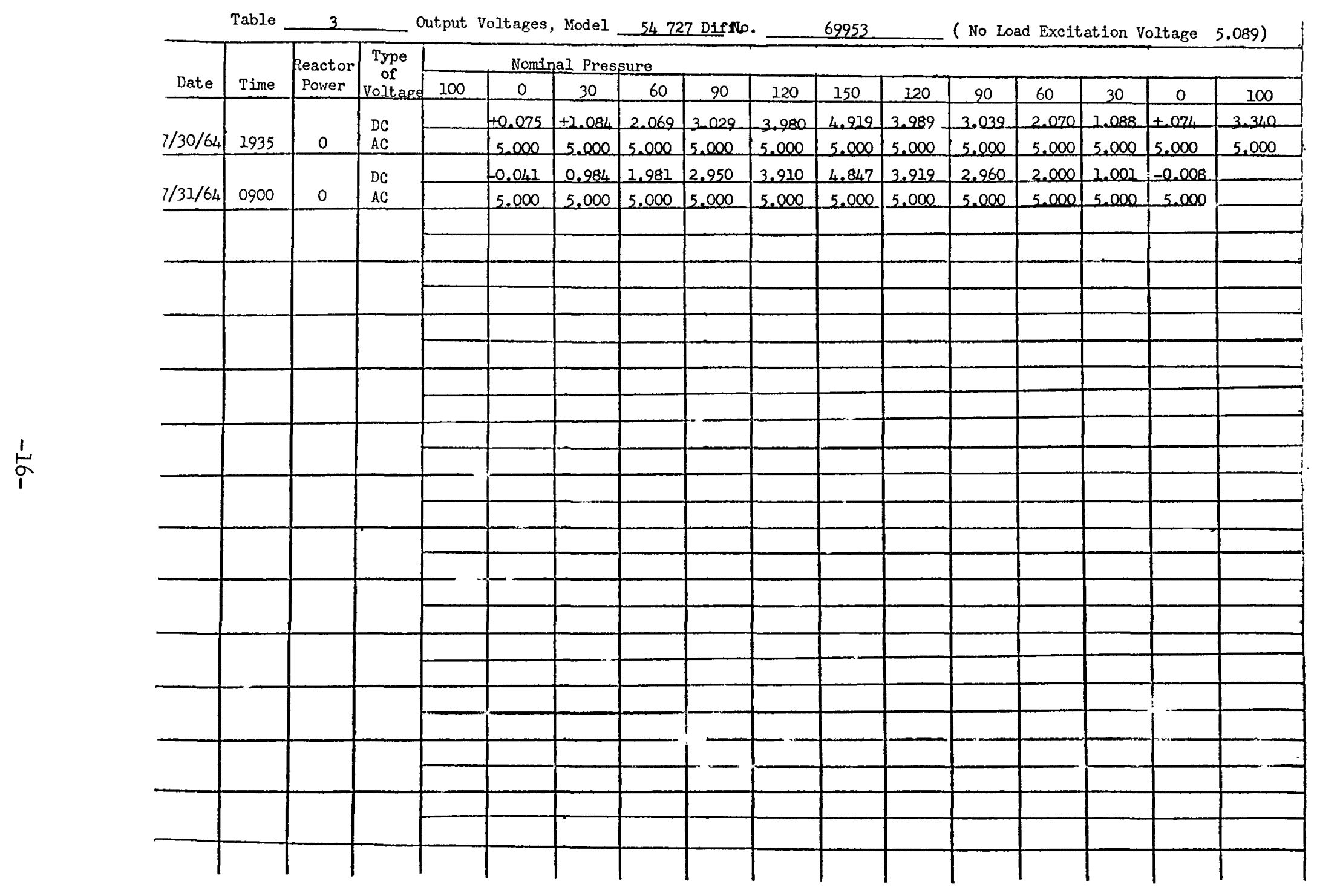


Table 3 Output Voltaces, Model 54.727 Dtff. No.

69953 (No Load Excitation Voltage 5.089)

\begin{tabular}{|c|c|c|c|c|c|c|c|c|c|c|c|c|c|c|c|c|}
\hline \multirow{2}{*}{ DATE } & \multirow{2}{*}{ TINE } & \multirow{2}{*}{$\begin{array}{r}\text { PEACTOR } \\
\text { POVER } \\
\end{array}$} & \multirow{2}{*}{$\begin{array}{c}\text { TYPE } \\
\text { OF } \\
\text { VOLTAGR } \\
\end{array}$} & \multicolumn{13}{|c|}{ NOMTNAL PRESSURE } \\
\hline & & & & 100 & 0 & 30 & 60 & 90 & 120 & 150 & 120 & 90 & 60 & 30 & 0 & 100 \\
\hline \multirow{2}{*}{$7 / 28 / 6$} & \multirow{2}{*}{1300} & \multirow[b]{2}{*}{0} & \multirow{2}{*}{$\begin{array}{l}\mathrm{DC} \\
\mathrm{AC}\end{array}$} & & -0.131 & 0.95 & 1.981 & 2.999 & 3.985 & 4.959 & 3.985 & 2.295 & 1.989 & 0.954 & -0.732 & \\
\hline & & & & & 5.000 & 5.000 & 5.000 & 5.000 & 5.000 & 5.000 & 5.000 & 5.000 & 5.000 & 5.000 & 5.000 & \\
\hline \multirow[b]{2}{*}{$7 / 28 / 6$} & \multirow[b]{2}{*}{1350} & \multirow[b]{2}{*}{0} & \multirow{2}{*}{$\begin{array}{l}\mathrm{DC} \\
\mathrm{AC}\end{array}$} & & -0.132 & 0.943 & 1.977 & 2.990 & 3.290 & 4.952 & 3.989 & 2.999 & 1.989 & 0.951 & -0.132 & \\
\hline & & & & & 5.000 & 5.002 & 5.002 & 5.002 & 5.002 & 5.002 & 5.002 & 5.002 & 5.002 & 5.002 & 5.002 & \\
\hline \multirow[b]{2}{*}{$7 / 29 / 6$} & \multirow[b]{2}{*}{0345} & \multirow[b]{2}{*}{0} & \multirow{2}{*}{$\begin{array}{l}\mathrm{DC} \\
\mathrm{AC} \\
\end{array}$} & & -0.194 & 0.867 & 1.921 & 2.919 & 3.909 & 4.885 & 3.902 & 2.929 & 1.913 & 0.880 & -0.181 & \\
\hline & & & & & 5.000 & 5.001 & 5.001 & 5.001 & 5.000 & 4.992 & 5.003 & 5.003 & 5.002 & 5.002 & 5.000 & \\
\hline \multirow{2}{*}{$7 / 29 / 6$} & \multirow[b]{2}{*}{1147} & \multirow[b]{2}{*}{0} & \multirow{2}{*}{$\begin{array}{l}\mathrm{DC} \\
\mathrm{AC} \\
\end{array}$} & & -0.1779 & 0.8829 & .9115 & 2.219 & 3.201 & 4.869 & 3.900 & 2.220 & 1.2199 & 0.894 & $=0.1690$ & \\
\hline & & & & & 5.000 & 5.000 & 4.999 & 4.999 & 4.999 & 4.999 & 4.999 & 4.999 & 4.995 & 4.997 & 4.993 & \\
\hline \multirow{2}{*}{$7 / 29 / 6$} & \multirow[b]{2}{*}{2035} & \multirow[b]{2}{*}{0} & \multirow{2}{*}{$\begin{array}{l}\mathrm{DC} \\
\mathrm{AC} \\
\end{array}$} & & -.169 & .890 & 1.218 & 2.919 & 3.919 & 4.892 & 3.929 & 2.931 & 1.926 & 0.897 & $=.760$ & \pm 3.259 \\
\hline & & & & & 5.001 & 5.001 & 5.001 & 5.001 & 5.001 & 5.001 & 5.001 & 5.001 & 5.001 & 5.001 & 5.001 & 5.001 \\
\hline & & & $D C$ & 3.259 & -0.160 & 0.903 & 1.925 & 2.930 & 3.921 & 4.899 & 3.929 & 2.939 & 2030 & 0.906 & $=0.152$ & 3.261 \\
\hline $7 / 29 / 61$ & 2150 & $100 \mathrm{~K} \cdot \mathrm{V}$ & $A C$ & 5.000 & 5.000 & 5.000 & 5.000 & 5.000 & 5.000 & 5.000 & 5,000 & 50 & 5,500 & |ممفـــ- & مסח.5. & 5000 \\
\hline & & & $\mathrm{DC}$ & 3.279 & $=0.770$ & -0.892 & 1.923 & 2.939 & 3.939 & L.206 & 3.920 & 2.934 & 1.931 & 0.896 & -0.168 & 3.269 \\
\hline $9 / 64$ & 2230 & 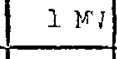 & $A C$ & 5 & 5,000 & 5 .0ad & 5.50 & 5000 & 5.000 & 5.000 & 5.000 & 5.000 & 5.000 & 5.000 & 5.000 & 5.000 \\
\hline & & & DC & 3.260 & $=0.163$ & 0.890 & 1.929 & 2.929 & 3.929 & 4.891 & 3.939 & 2.942 & 1.938 & 0.908 & -0.157 & 3.282 \\
\hline $9 / 61$ & 2350 & ] $N T$ & $A C$ & 5.000 & 5.000 & 5.000 & 5.000 & 5.000 & 5.000 & 5.000 & 5.000 & 5.000 & 5.000 & 5.000 & 5.000 & 5.000 \\
\hline & & & $D C$ & 3.289 & -0.261 & 0.903 & 1.947 & 2.959 & 3.942 & 4.926 & 3.959 & 2.969 & 1.953 & 0.904 & -0.161 & 3.288 \\
\hline & 0035 & $5 \mathrm{MI}$ & $A C$ & 5.000 & 5.000 & $5.00 \mathrm{~d}$ & 5.000 & 5.000 & 5.000 & 5.000 & 5.000 & 5.000 & 5.000 & 5.000 & 5.000 & 5.000 \\
\hline & & & DC & 3.309 & $=0.151$ & 0.913 & 1.953 & 2.259 & 3.259 & 4.939 & 3.959 & 2.971 & 1.965 & 0.929 & -0.150 & 3.299 \\
\hline & 0200 & $5 \mathrm{MI}$ & $\mathrm{AG}$ & 5.000 & 5.000 & 5.000 & 5.000 & 5,000 & 5.000 & 5.000 & 5.000 & 5.000 & 5.000 & 5.000 & 5.000 & 5.000 \\
\hline & & & DC & 3.329 & 0.258 & 0.927 & 1.965 & 2.989 & 3.979 & {$[4.96]$} & 3.979 & 2.989 & 1.971 & 0.927 & -0.159 & 3.327 \\
\hline & 0230 & $10 \mathrm{Ml}$ & $\mathrm{AC}$ & 5.000 & 5.000 & $5.00 \mathrm{~d}$ & 5.000 & 5.000 & 5.000 & 5.000 & 5.000 & 5.000 & 5.000 & 5.000 & 5.000 & 5.000 \\
\hline & & & DC & 3320 & -0.159 & 0.915 & 1.962 & 2.989 & 3.989 & 4.969 & 4.000 & 2.989 & 1.973 & 0.234 & -0.152 & 3.319 \\
\hline $7 / 30 / 64$ & 0350 & $101 \%$ & $\mathrm{AC}$ & 5.000 & 5.000 & 5.000 & 5.000 & 5.000 & 5.000 & 5.000 & 5.000 & 5.000 & 5.000 & 5.000 & 5.000 & 5.000 \\
\hline & & & $\mathrm{DC}$ & 3.339 & $-0,159$ & 0.924 & 1.974 & 2.989 & 4.006 & 4.993 & 4.012 & 3.003 & 1.980 & 0.933 & $=0.7 .56$ & 3.329 \\
\hline & 0430 & $15 \mathrm{Mr}$ & AC & 5.000 & 5.000 & 5.000 & 5.000 & 5.000 & 5.000 & 5.000 & 5.000 & 5.000 & 5.000 & 5.000 & 5.000 & 5.000 \\
\hline & & & $\mathrm{DC}$ & 3.320 & -0.148 & 0.930 & 1.976 & 3.000 & 4.009 & 4.983 & 4.021 & 3.009 & 1.985 & -0.234 & -0.142 & 3.322 \\
\hline 16 & 0600 & $15 \mathrm{MI}$ & $\Lambda \mathrm{C}$ & 5.000 & 5.000 & 5.000 & 5.000 & 5.000 & 5.000 & 5.000 & 5.000 & 5.000 & 5.000 & 5.000 & 5.000 & 5.000 \\
\hline & & & & & & & & & & & & & & & & \\
\hline
\end{tabular}




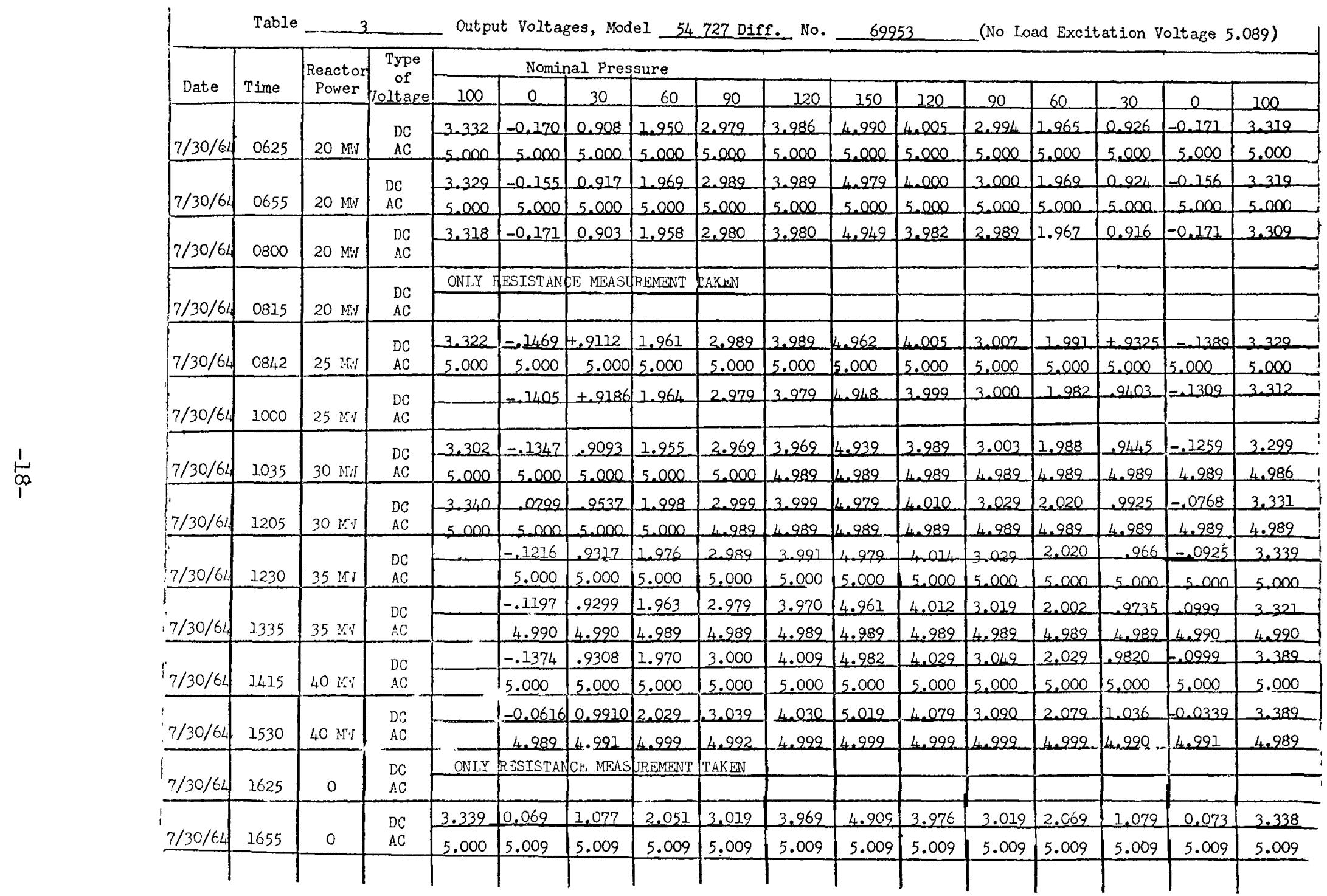


Table

Output Voltages, Model 54727 Diff. No. 69952

(No Load Excitation Voltage 5.089)

\begin{tabular}{|c|c|c|c|c|c|c|c|c|c|c|c|c|c|c|c|c|}
\hline \multirow{2}{*}{ DATE } & \multirow{2}{*}{ TIME } & \multirow{2}{*}{$\begin{array}{r}\text { REACTOR } \\
\text { POVER } \\
\end{array}$} & \multirow{2}{*}{$\begin{array}{c}\text { TYPE } \\
\text { OF } \\
\text { VOLTAG } \\
\end{array}$} & \multicolumn{13}{|c|}{ NOMTNAL PRESSURE } \\
\hline & & & & 100 & 0 & 30 & 60 & 90 & 120 & 150 & 120 & 90 & 60 & 30 & 0 & 100 \\
\hline \multirow{2}{*}{$7 / 28 / 6$} & \multirow{2}{*}{1300} & \multirow[b]{2}{*}{0} & \multirow{2}{*}{$\begin{array}{l}\mathrm{DC} \\
\mathrm{AC}\end{array}$} & & -0.204 & 0.930 & 2.019 & 3.099 & 4.159 & 5.204 & 4.159 & 3.099 & 7.029 & 0.934 & $=0.201$ & \\
\hline & & & & & 5.000 & 5.000 & 5.000 & 5.000 & 5.000 & 5.000 & 5.000 & 5,000 & 5.000 & 5.000 & 5.000 & \\
\hline \multirow{2}{*}{$7 / 28 / 6$} & \multirow[b]{2}{*}{1350} & \multirow[b]{2}{*}{0} & \multirow{2}{*}{$\begin{array}{l}\mathrm{DC} \\
\mathrm{AC} \\
\end{array}$} & & -0.202 & 0.922 & 2.009 & 3.092 & 4.159 & 5.209 & - & 3.092 & 2.023 & 0.930 & -0.201 & \\
\hline & & & & & 5.000 & 5.002 & 5.002 & 5.002 & 5.002 & 5.002 & 5.002 & 5.002 & 5,002 & -5002 & 5.002 & \\
\hline \multirow[b]{2}{*}{$7 / 29 / 6$} & \multirow[b]{2}{*}{0345} & \multirow[b]{2}{*}{0} & \multirow{2}{*}{$\begin{array}{l}\mathrm{DC} \\
\Lambda \mathrm{C} \\
\end{array}$} & & -0.192 & 0.899 & 1.983 & 3,059 & 4.179 & 5.172 & 4.112 & 3.060 & 1.987 & 0.899 & $=0.207$ & \\
\hline & & & & & 5.000 & 5.001 & 5.001 & 4.999 & 4.999 & 4.992 & 5.003 & 5.003 & 5.002 & 5.002 & 5.000 & \\
\hline \multirow{2}{*}{$7 / 29 / 6$} & \multirow[b]{2}{*}{1147} & \multirow[b]{2}{*}{0} & \multirow{2}{*}{$\begin{array}{l}\mathrm{DC} \\
\mathrm{AC} \\
\end{array}$} & & +.2321 & +.8728 & 1.960 & 3.029 & 4.072 & 5.119 & 4.072 & 3.029 & 1.963 & 8830 & .2269 & \\
\hline & & & & & 5.000 & 4.999 & 4.999 & 4.999 & 4.999 & 4.999 & 4.999 & 4.999 & 4.997 & 4.997 & 4.993 & \\
\hline \multirow[b]{2}{*}{$.7 / 29 / 64$} & \multirow[b]{2}{*}{2035} & \multirow[b]{2}{*}{0} & \multirow{2}{*}{$\begin{array}{l}\mathrm{DC} \\
\mathrm{AC}\end{array}$} & & -.223 & 0.880 & 1.965 & 3,029 & 4.099 & 5.242 & 4.107 & 3.040 & 1.972 & 0.888 & -.215 & +3.389 \\
\hline & & & & & 5.001 & 5.001 & 5.001 & 5.001 & 5.001 & 5.001 & 5.001 & 5.001 & 5.001 & 5.001 & 5.001 & 5.001 \\
\hline & & & $\mathrm{DC}$ & 3.372 & -0.224 & 0.885 & 1.962 & 3.029 & 4.089 & 5.139 & 4.099 & 30.09 & 1.970 & 0.890 & -0.214 & 3.389 \\
\hline $.7 / 29 / 64$ & 2150 & $100 \mathrm{~K} \cdot \mathrm{J}$ & $A C$ & 5.000 & 5.000 & 5.000 & 5.000 & 5.000 & 5.000 & 5.000 & 5.000 & 5000 & 5.000 & 5.000 & 5.000 & 5.000 \\
\hline & & & $D C$ & 3.419 & -0.214 & 0.894 & 6.982 & 3.059 & 4.129 & 5.171 & 4.119 & 3.050 & 1.985 & 0.895 & -0.216 & 3.409 \\
\hline $9 / 64$ & 2230 & $1 \mathrm{MJ}$ & $A C$ & 5.000 & 5.000 & 5.000 & 5.000 & 5.000 & 5.000 & 5.000 & 4.999 & 5.000 & 5.000 & 5.000 & 5.000 & 5.000 \\
\hline & & & $\mathrm{DC}$ & 3.389 & -0.226 & 0.884 & 1.971 & 3.029 & 4.099 & 5.239 & 4.100 & 3.049 & 1.976 & 0.897 & $=0.222$ & 3.09 \\
\hline $7 / 29 / 64$ & 2350 & $1 \mathrm{MN}$ & $A C$ & 5.000 & 5.000 & 5.000 & 5.000 & 5.000 & 5.000 & 5.000 & 5.000 & 5,000 & 5.000 & 5.000 & 5.000 & 5.000 \\
\hline & & & $\mathrm{DC}$ & 3.419 & -0.228 & 0.885 & 1.989 & 3.069 & 4.129 & 5.189 & 4.139 & 3.070 & 2.001 & 0.886 & $=0.222$ & $3 / 29$ \\
\hline $1 / 64$ & 0035 & $5 \times 1$ & $\Lambda C$ & 5.000 & 5.000 & 5.000 & 5.000 & 5.000 & 5.000 & 5.000 & 5.000 & 5.000 & 5.000 & 5.000 & 5.000 & 5,000 \\
\hline & 10ว00 & & DC & 3.431 & -0.225 & 0.891 & 1.992 & 3.061 & 4.131 & 5.189 & 4.139 & 3.079 & 2.001 & 0.908 & -0.223 & 3.29 \\
\hline & 0200 & $5 M$ & $A C$ & 5.000 & 5.000 & 5.000 & 5.000 & 5.000 & 5.000 & 5.000 & 5.000 & 5.000 & 5.000 & 5.000 & 5.000 & 5.000 \\
\hline & & & $\mathrm{DC}$ & 3.471 & -0.217 & 0.912 & 2.029 & 3.119 & 4.179 & 5.250 & 4.780 & 3.179 & 2.029 & 0.926 & -0.212 & 3,479 \\
\hline 164 & 0230 & $10 \mathrm{Mr}$ & $A C$ & 5.000 & 5.000 & 5.000 & 5.000 & 5.000 & 5.000 & 5.000 & 5.000 & . & 5.00 & 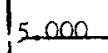 & 5000 & 5,000 \\
\hline & & & $\mathrm{DC}$ & 3.530 & -0.138 & 0.983 & 2008 & 3.175 & b.239 & 5.292 & 4.259 & 3.179 & 2.099 & 1.007 & -0.122 & -3.529 \\
\hline $30 / 64$ & 0350 & $10 \mathrm{Mv}$ & $\mathrm{AC}$ & م0مــــ. & . م00.0. & 5.000 & 5.000 & 5.000 & 5.000 & 5.002 & 5.000 & .5 .000 & 5.000 & 5.000 & 5.000 & 5.000 \\
\hline & 0 & 7 & $D C$ & 3.509 & -0.168 & 0.960 & 2.059 & 3.139 & & 5.279 & 4.231 & 3,769 & 2.079 & 0.982 & -0.153 & 3,496 \\
\hline & 0430 & $15 \mathrm{M}$ & $\mathrm{AC}$ & 5.000 & 5.000 & 5.000 & 5.000 & 5.000 & 5.000 & 5.000 & 5.000 & 5.000 & 5.000 & 5.000 & 5.000 & 5.000 \\
\hline & & & $D C$ & 3.459 & -0.148 & 0.961 & 2.049 & 3.112 & 4.179 & 5.210 & 4.180 & 3.129 & 2.052 & 0.966 & 0.142 & 3.459 \\
\hline$=/ 64$ & 0600 & $15 \mathrm{KI}$ & $\mathrm{AC}$ & 5.000 & 5.000 & 5.000 & 5.000 & 5.000 & 5.000 & 5.000 & 5.000 & 5.000 & 5.000 & 5.000 & 5.000 & 5.000 \\
\hline & & & & & & & & & & & & & & & & \\
\hline
\end{tabular}




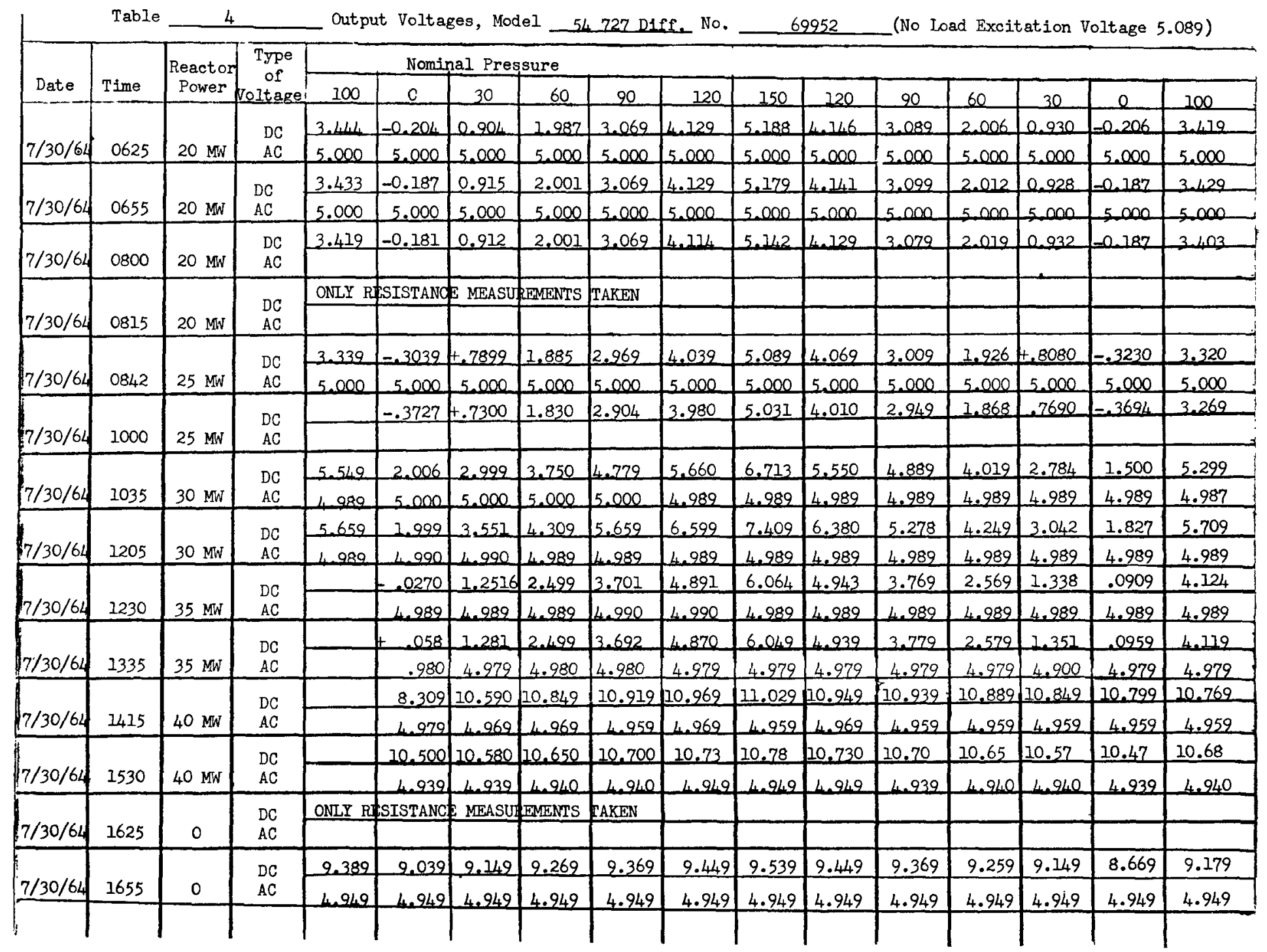




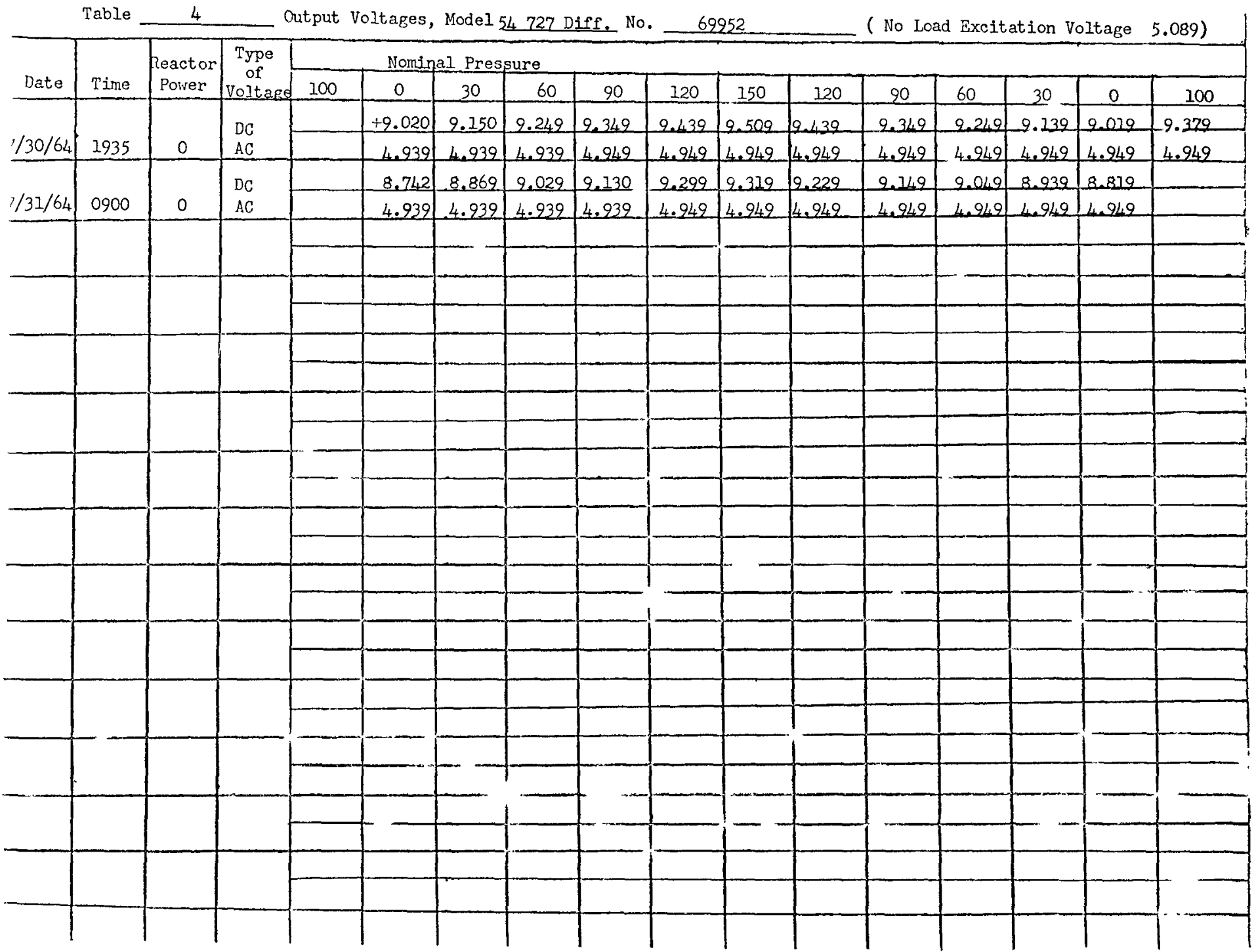


Table 5 Output Voltages, Model 54.726 Absolute No.

70639

(No Load Excitation Voltage 5.089)

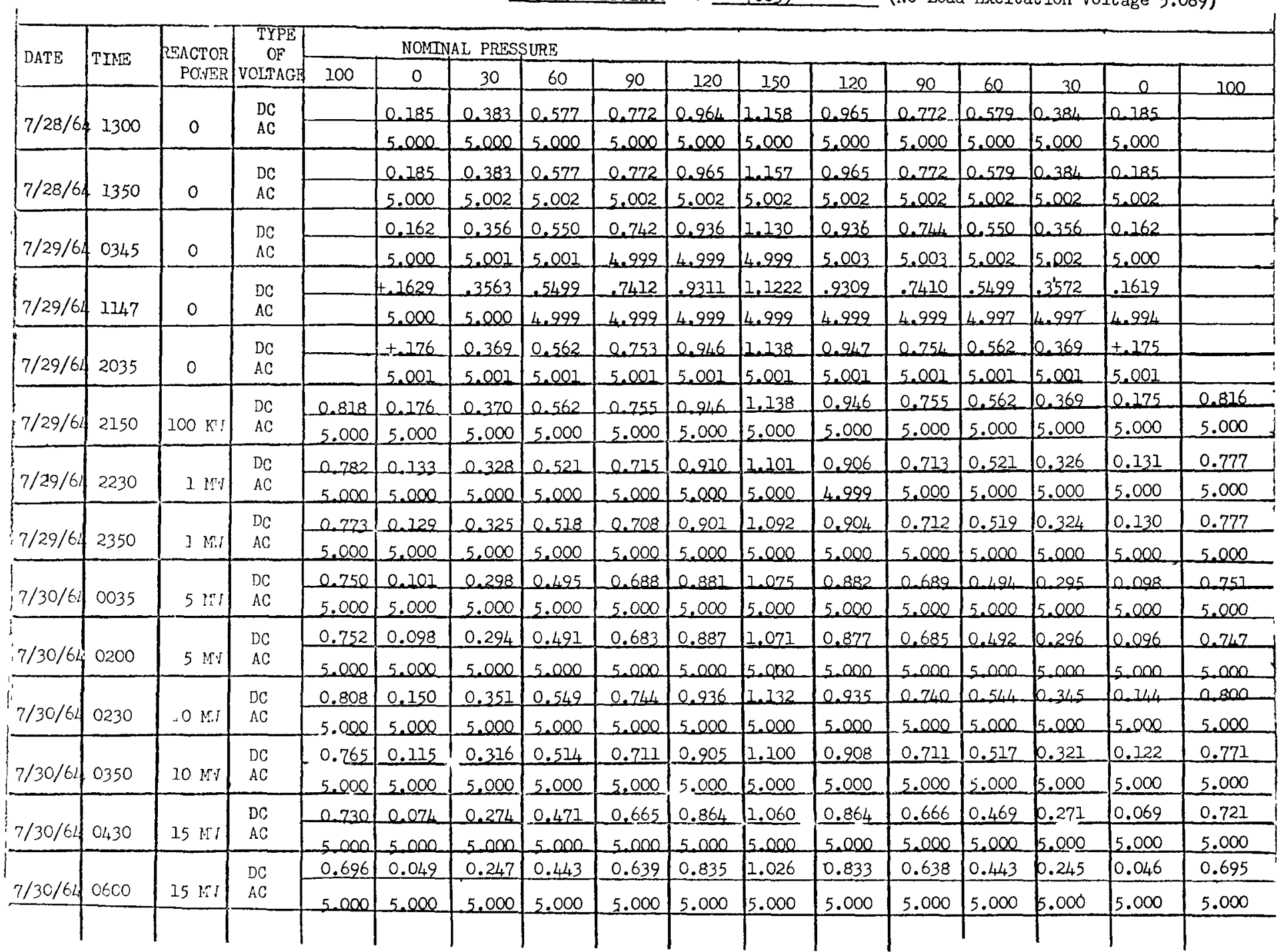




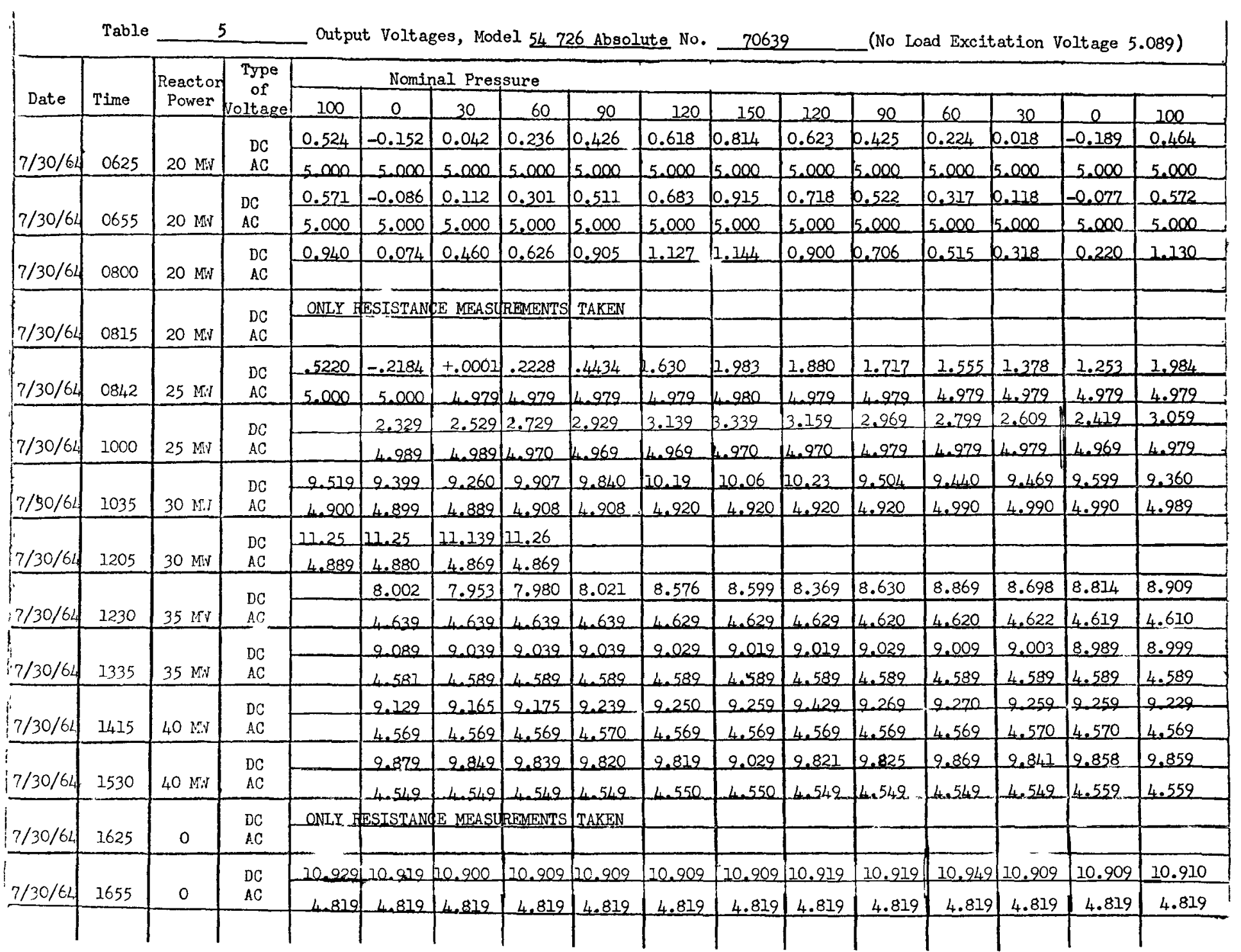




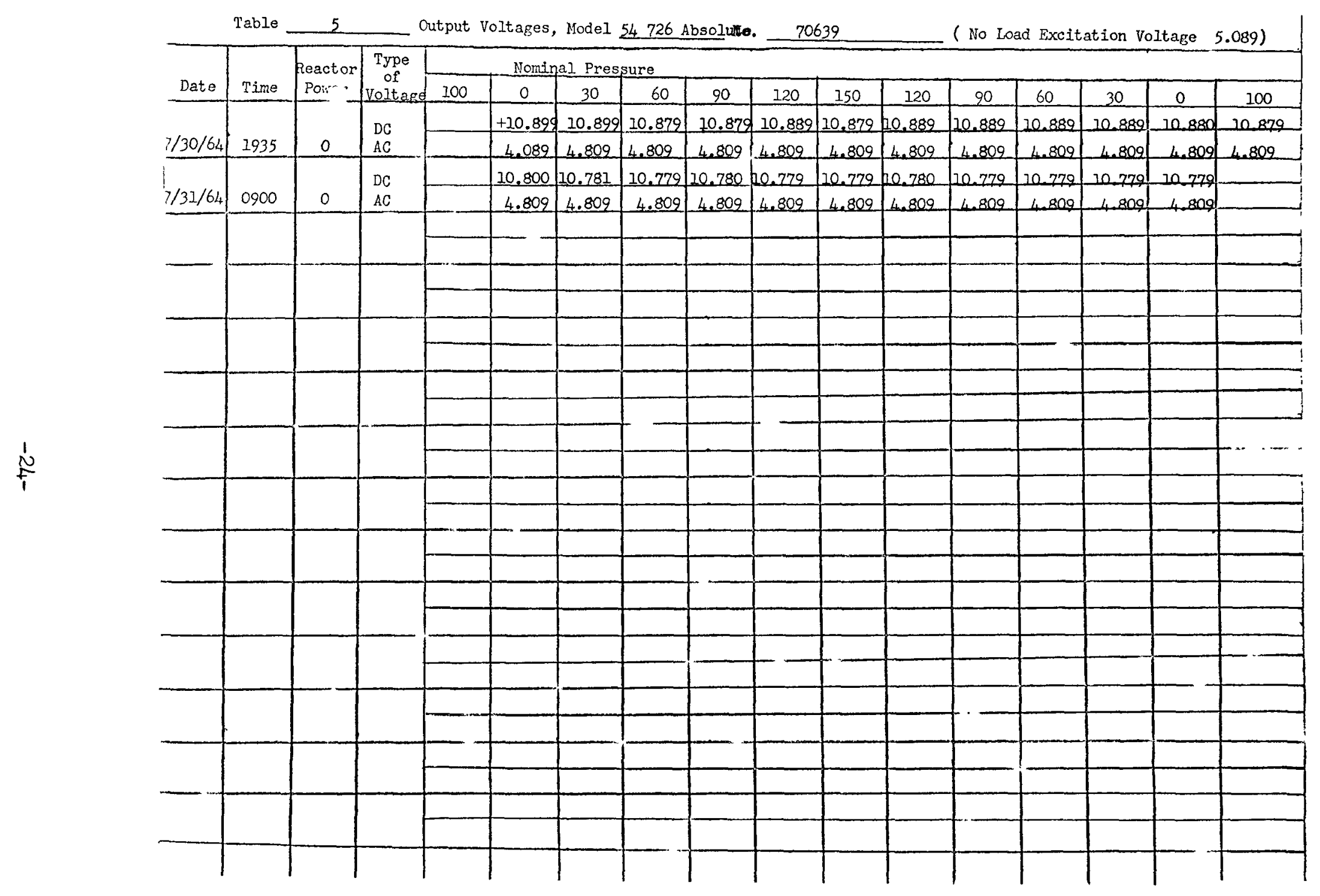


Table 6

Output Voltage, Model 54726 absolute No.

69955

(No Load Excitation Voltage 5.089)

\begin{tabular}{|c|c|c|c|c|c|c|c|c|c|c|c|c|c|c|c|c|}
\hline \multirow{2}{*}{ DATE } & \multirow{2}{*}{ TINE } & \multirow{2}{*}{$\begin{array}{r}\text { REACTOR } \\
\text { PO } \sqrt{E R} \\
\end{array}$} & \multirow{2}{*}{$\begin{array}{c}\text { TYPE } \\
\text { OF } \\
\text { VOITAGS }\end{array}$} & \multicolumn{5}{|c|}{ NO'TNAL PRESSURE } & \\
\hline & & & & 100 & 0 & 30 & 60 & 90 & 120 & 150 & 120 & 90 & 60 & 30 & 0 & 100 \\
\hline \multirow{2}{*}{$7 / 28 / 6$} & \multirow[b]{2}{*}{1300} & \multirow[b]{2}{*}{0} & \multirow{2}{*}{$\begin{array}{l}\text { Di: } \\
\therefore .3 \\
\end{array}$} & & 0.049 & 0.258 & 0.461 & 0.665 & 0.867 & 1.069 & 0.868 & 0.665 & 0.462 & 0.258 & 0.048 & \\
\hline & & & & & 5.000 & 5.000 & 5.000 & 5.000 & 5.000 & 5.000 & 5.000 & 5.000 & 5.000 & 5.000 & 5.000 & \\
\hline \multirow[b]{2}{*}{$7 / 28 / 6$} & \multirow[b]{2}{*}{1350} & \multirow[b]{2}{*}{0} & \multirow{2}{*}{$\begin{array}{l}\mathrm{DC} \\
\mathrm{AC}\end{array}$} & & 0.048 & 0.256 & 0.459 & 0.664 & 0.867 & 1.062 & 0,868 & 0.665 & 0.462 & 0.257 & 0.048 & \\
\hline & & & & & - & 5.002 & 5.002 & -5002 & 5.002 & 5,002 & 5.002 & 5.002 & 5.002 & 5.002 & 5.002 & \\
\hline \multirow[b]{2}{*}{$7 / 29 / 64$} & \multirow[b]{2}{*}{0345} & \multirow[b]{2}{*}{0} & \multirow{2}{*}{$\begin{array}{l}\mathrm{DC} \\
\mathrm{AC} \\
\end{array}$} & & 0.024 & 0.228 & 0,432 & 0.634 & 0.836 & 1.055 & 0.837 & 0.636 & 0.432 & 0.229 & 0.024 & \\
\hline & & & & & 5.000 & 5.001 & 5.001 & 4.299 & 4.999 & 4.999 & 5.003 & 5.003 & 5.002 & 5,000 & 5.000 & \\
\hline \multirow[b]{2}{*}{$7 / 29 / 64$} & \multirow[b]{2}{*}{1147} & \multirow[b]{2}{*}{0} & \multirow{2}{*}{$\begin{array}{l}\mathrm{DC} \\
\mathrm{AC}\end{array}$} & & -0370 & $-24,09$ & I & .6449 & .8442 & 2.0456 & .8450 & .6566 & .4462 & .2329 & .0389 & \\
\hline & & & & & .4799 & 4.099 & 6.992 & 4.999 & 4.999 & 4.999 & 4.989 & 4.999 & 4.997 & 4.990 & 4.994 & \\
\hline \multirow[b]{2}{*}{$7 / 29 / 64$} & \multirow[b]{2}{*}{2035} & \multirow[b]{2}{*}{0} & $\mathrm{DC}$ & & . & 0.250 & 0.453 & 0.654 & 0.856 & 1.058 & 0.858 & 0.656 & . & 0251 & . & 772 \\
\hline & & & $A C$ & & 5.001 & 5,002 & 5.001 & 5 . & 5.007 & 5.007 & 5.002 & 5,001 & 5.002 & 5.001 & 5.002 & 5.001 \\
\hline & & & $\mathrm{DC}$ & 0.724 & 10.048 & 0.253 & 0.454 & 0.656 & 0.857 & 1,058 & -8.82 & 0.657 & 0.454 & 0.252 & 0.048 & 0.722 \\
\hline $7 / 29 / 64$ & 2150 & $100 \mathrm{Ki}$ & $A C$ & 5.000 & 5.000 & 5.000 & 5.000 & 5.000 & 5,000 & 5.000 & 5.000 & 5.000 & 5.000 & 5.000 & 5.000 & 5.000 \\
\hline & & & $D C$ & 0.709 & 0.029 & 0.235 & 0.439 & 0.641 & 0.846 & 1.047 & 0.843 & 0.641 & 0.439 & 0.235 & 0.030 & 0.708 \\
\hline & 2230 & $\begin{array}{lll}3 & 11\end{array}$ & $\mathrm{AC}$ & 5,000 & 5.000 & 5.000 & 5.000 & 5.000 & 5.000 & 5.000 & 4.989 & 4.989 & 4.989 & 5.000 & 5.000 & 4.990 \\
\hline & & & $\mathrm{DC}$ & 0.695 & 0.078 & 0.223 & 0.427 & 0.627 & 0.830 & 1.030 & 0.832 & 0.632 & 0.429 & 0.225 & 0.021 & 0.700 \\
\hline $7 / 29 / 64$ & 2350 & $12+1$ & $\mathrm{AC}$ & 5.000 & 5.000 & 5.000 & 5.000 & 5.000 & 5.000 & 5.000 & 5.000 & 5.000 & 5.000 & 5.000 & 5.000 & 5.000 \\
\hline & & & $D C$ & مـ687 & fo.003 & 0.211 & fe.42 & 0.621 & 0.824 & 1.027 & 0.824 & 0.622 & 0.428 & 0.210 & 0.004 & 0.688 \\
\hline $0 / 64$ & 0035 & $5 \mathrm{NI}$ & $\mathrm{AC}$ & 5.000 & 5.000 & 5.000 & 5.000 & 5.000 & 5.000 & 5.000 & 5.000 & 5.000 & 5.000 & 5.000 & 5.000 & 5.000 \\
\hline & & & $\mathrm{DC}$ & 0.690 & 0.004 & 0.212 & 0.427 & 0.612 & 0,823 & 1.026 & 0.824 & 0.622 & 0.418 & 0.213 & 0.004 & 0.687 \\
\hline & $0<00$ & 5 M. & $A C$ & 5000 & 5.000 & 5.000 & 5000 & 5.000 & 5.000 & 5.000 & 5.000 & 5.000 & 5.000 & 5.000 & 5.000 & 5.000 \\
\hline & & & $\mathrm{DC}$ & 0.710 & 0.012 & 0.227 & 0.435 & 0.641 & 0.84 & 1.052 & 0.845 & 0.647 & 0.435 & 10.228 & |م.027 & 0.708 \\
\hline $7 / 30 / 64$ & 0230 & $10 \mathrm{lr}$ & $\mathrm{AC}$ & 5.000 & 5.000 & 5.000 & 5.000 & 5.000 & 5.000 & 5.000 & 5.000 & 5.000 & 5000 & مع0.5 & 5.000 & -5.000 \\
\hline & & & $\mathrm{DC}$ & 0.691 & 0.002 & 10.212 & 0.420 & 0.625 & 0.831 & 7.034 & 10.831 & 0.623 & (6. & 0.212 & 0.002 & 0.690 \\
\hline $30 / 64$ & 0350 & $30 \mathrm{KI}$ & $A C$ & 5.000 & 5.000 & 5.000 & 5.000 & 5,000 & 5,000 & 5.000 & 5.000 & .5 .000 & 5.000 & 5.000 & 5.000 & 5.000 \\
\hline & & & $D C$ & 0.721 & 0.030 & 0.239 & 0.447 & 0.652 & 0.861 & 1.067 & 0.861 & 0.654 & 0.447 & 0.239 & 0.029 & 0.718 \\
\hline & 0430 & $1515 \pi$ & $\Lambda C$ & مصمـــ & 5.000 & 5.000 & 5.000 & 5.000 & 5.000 & 5.000 & 5.000 & 5.000 & 5.000 & 5.000 & 5.000 & 5.000 \\
\hline & & & $\mathrm{DC}$ & 0.713 & 0.031 & 0.239 & 0.444 & 0.650 & 0.855 & 1.057 & 0.853 & 0.648 & 0.443 & 0.236 & 0.029 & 0.713 \\
\hline $0 / 61$ & 0600 & $15 \mathrm{NH}$ & $\Lambda C$ & 5.000 & 5.000 & 5.000 & 5.000 & 5.000 & 5.000 & 5.000 & 5.000 & 5.000 & 5.000 & 5.000 & 5.000 & 5.000 \\
\hline
\end{tabular}




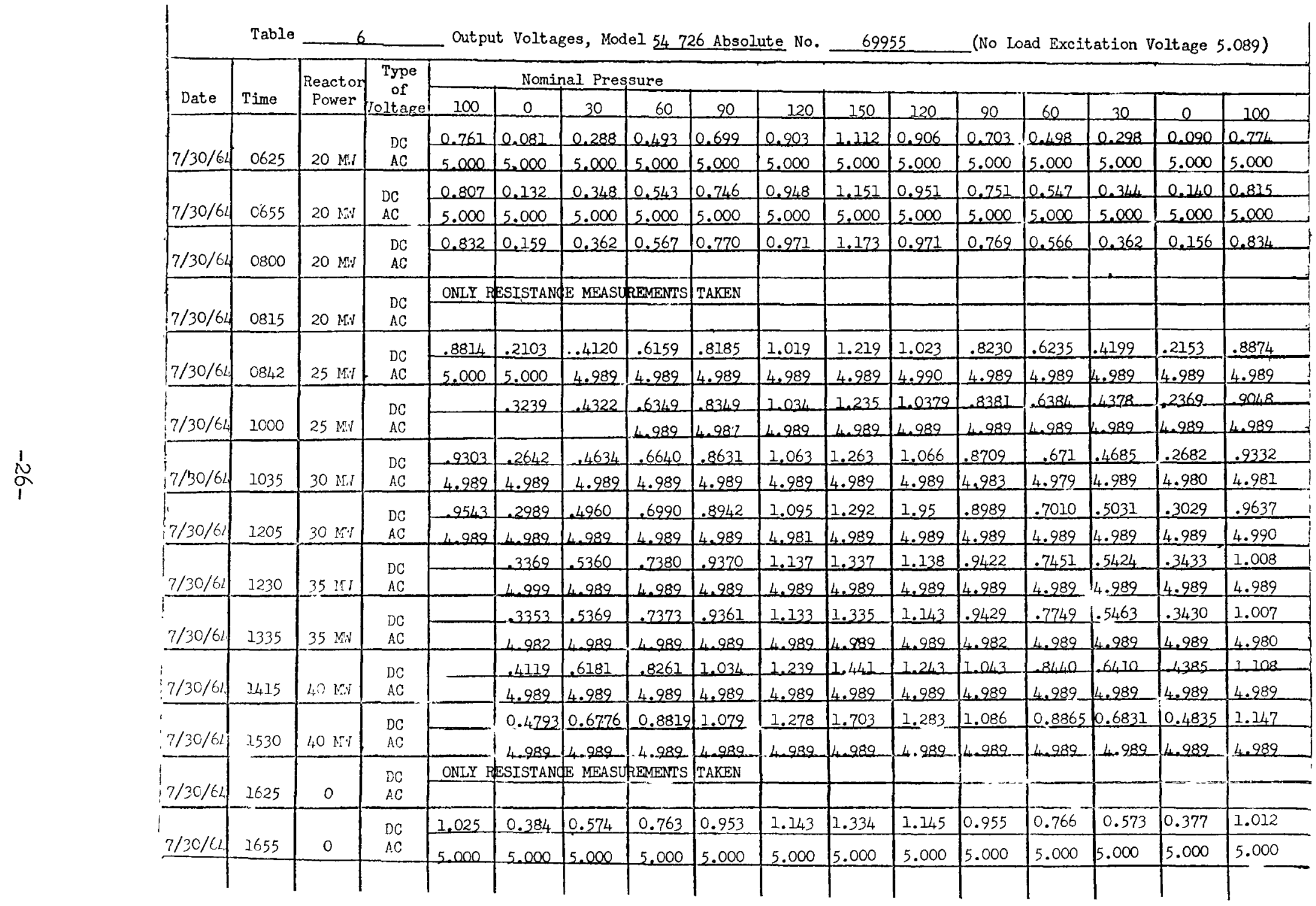




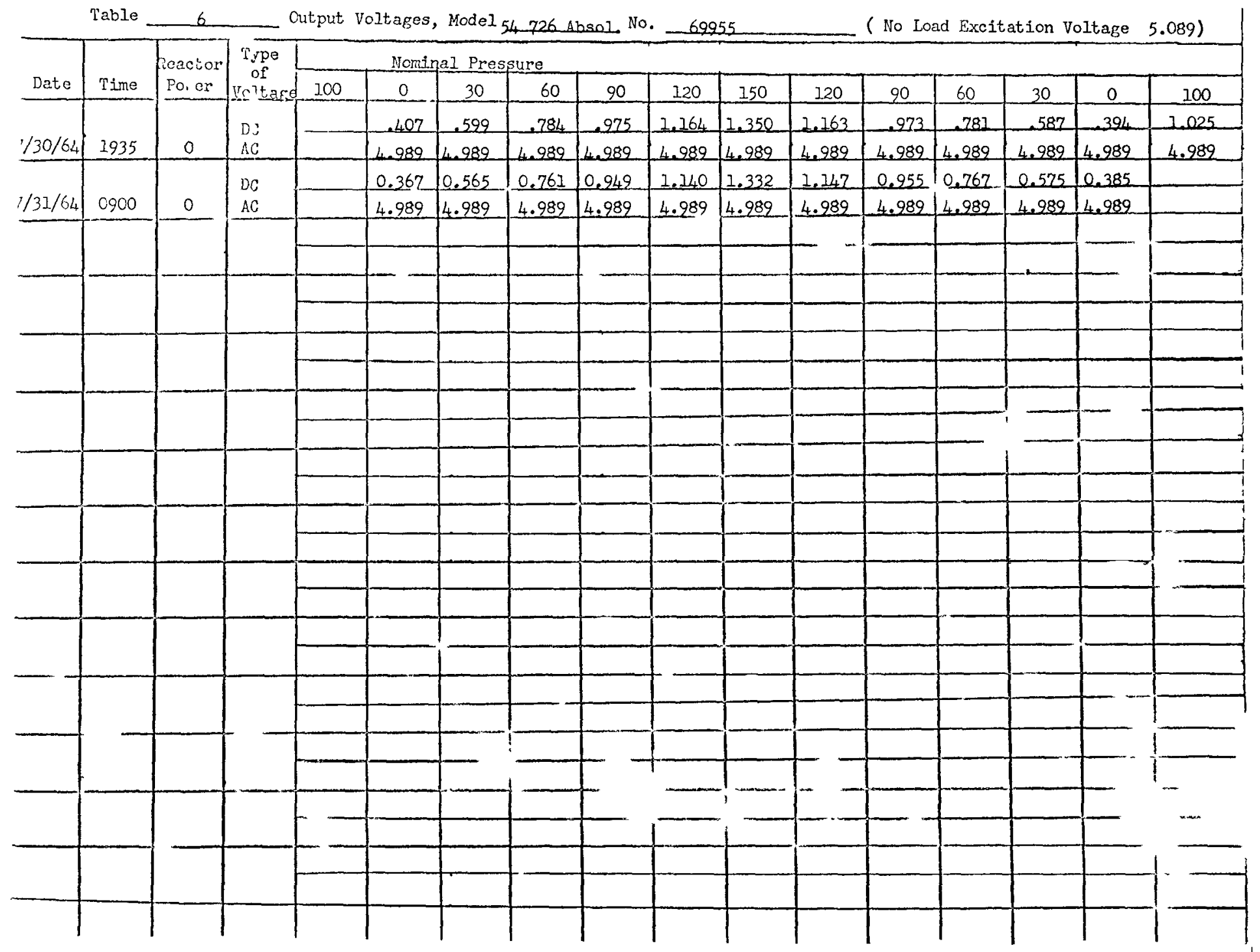




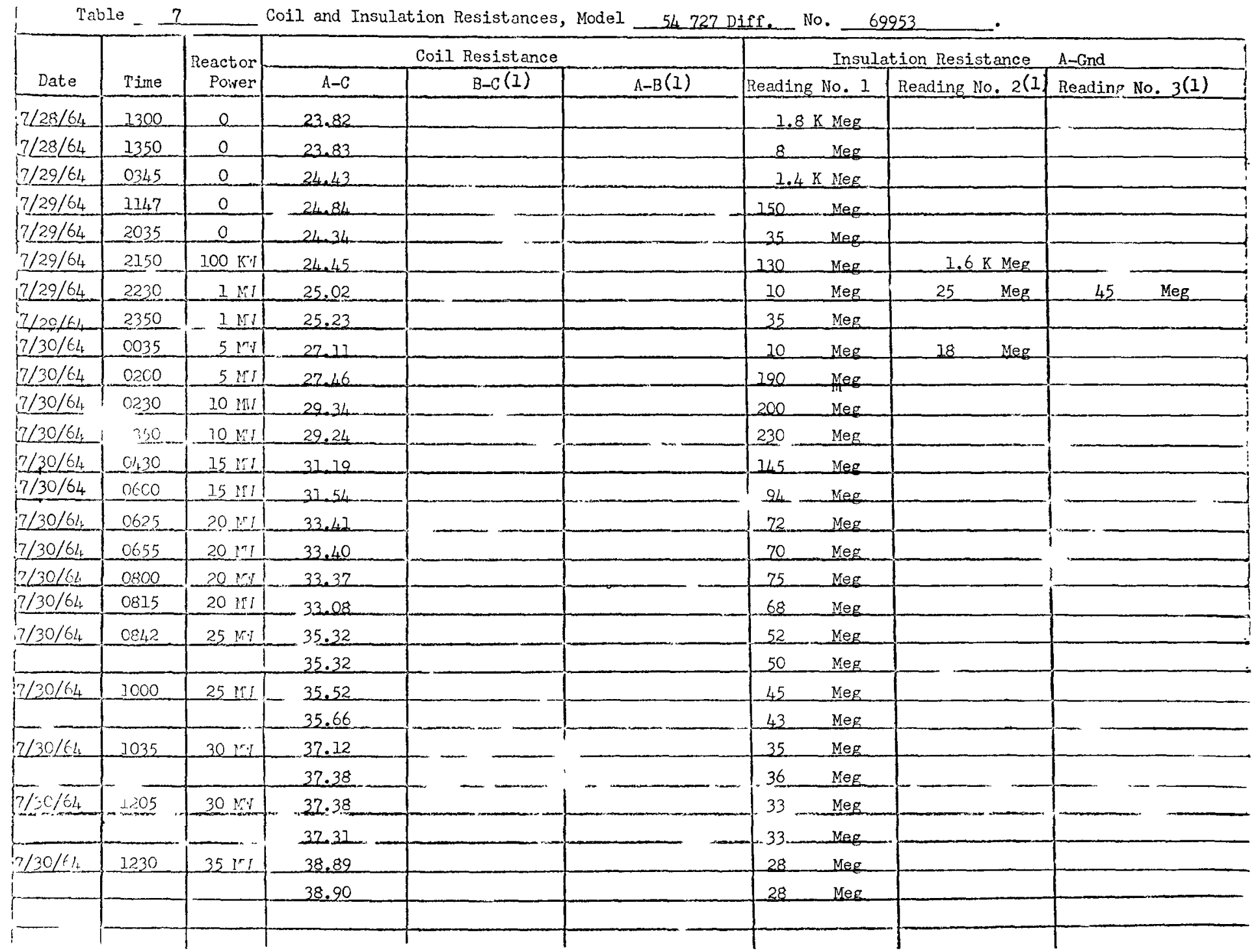


Table 7 Coil and Insulation Resistances, Model 54727 Diff._._No. __ 69953

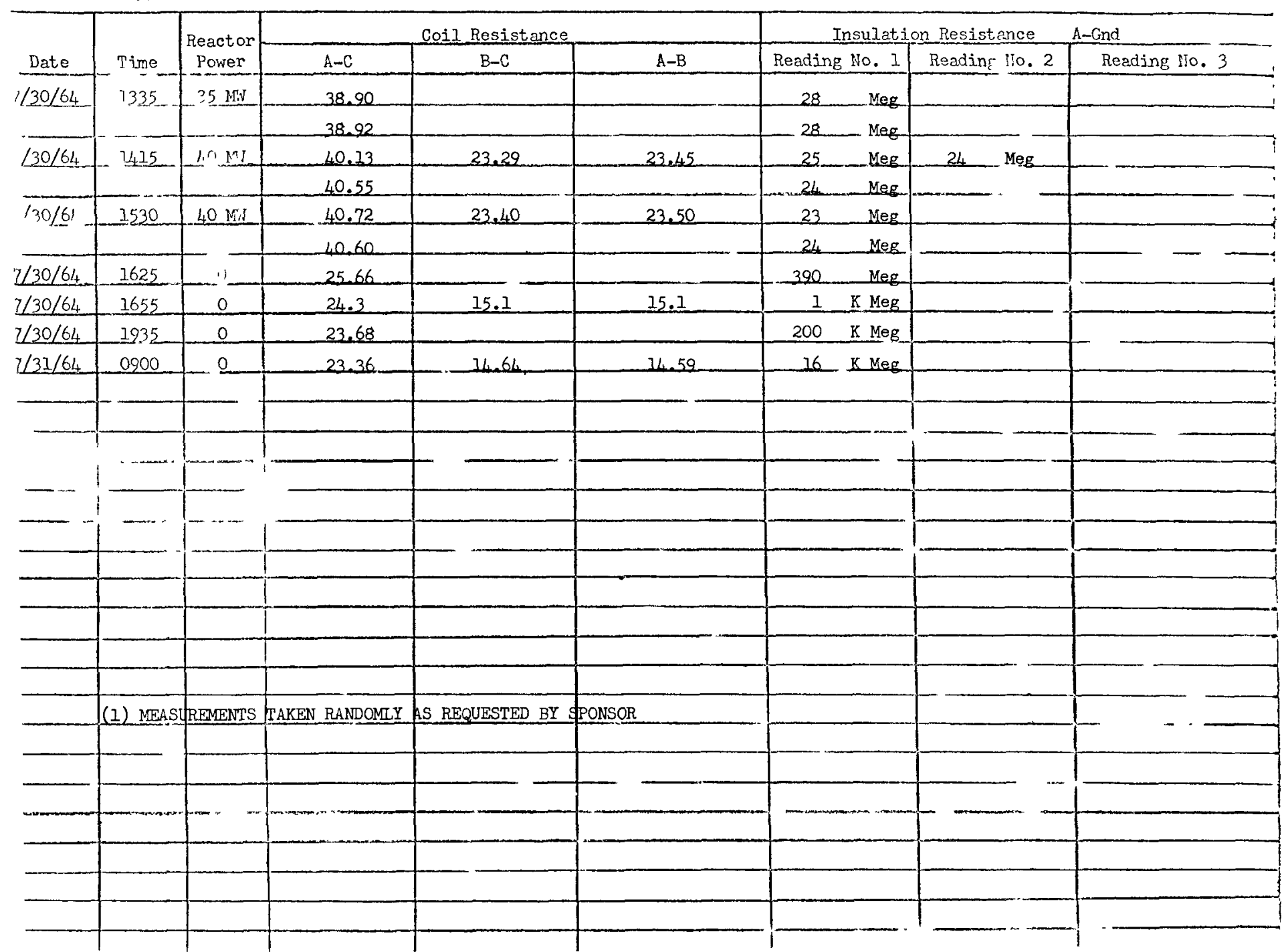


Table 8

Coil and Insulation Resistances, Model 54727 Diff. No. 69952

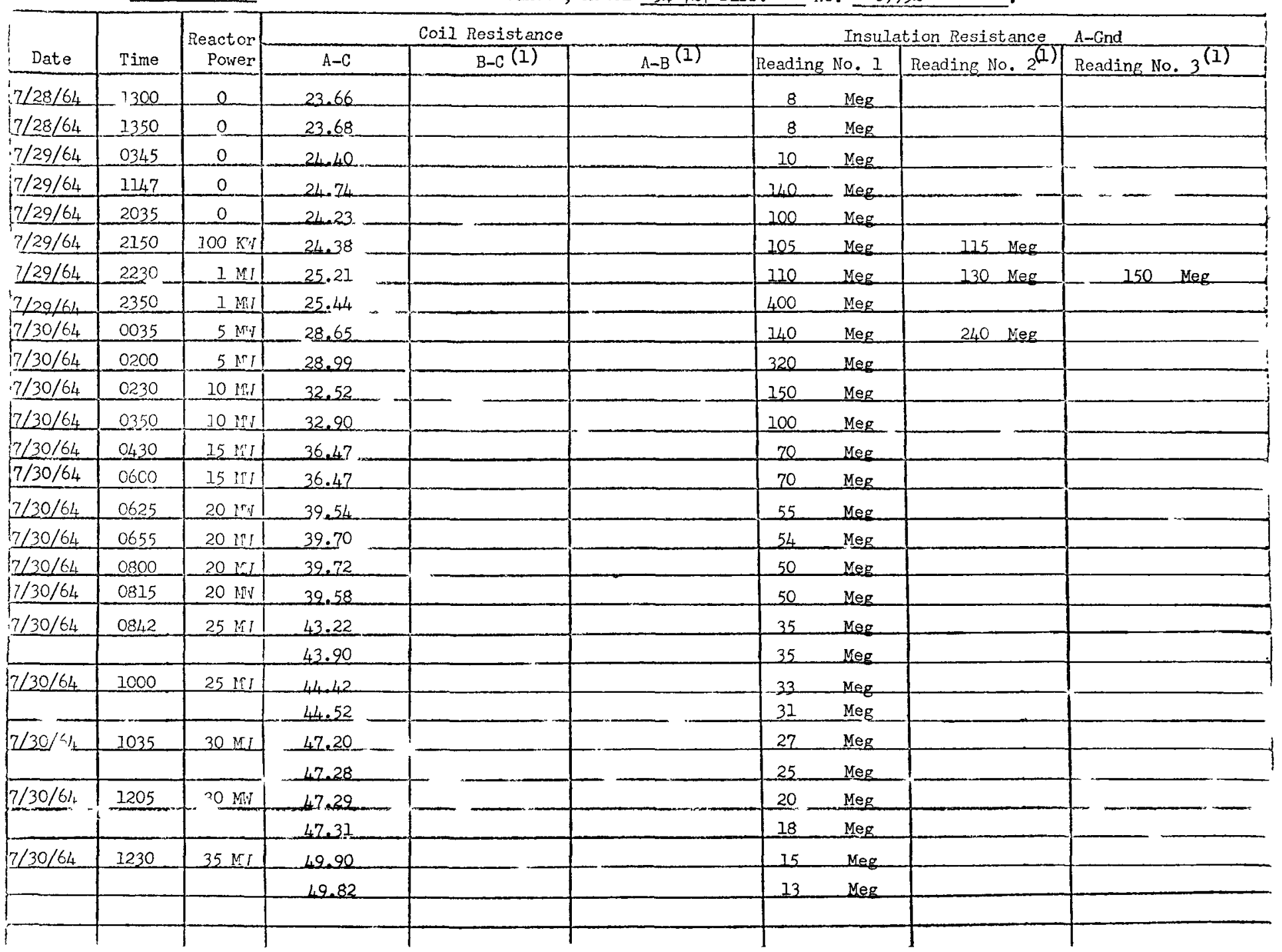




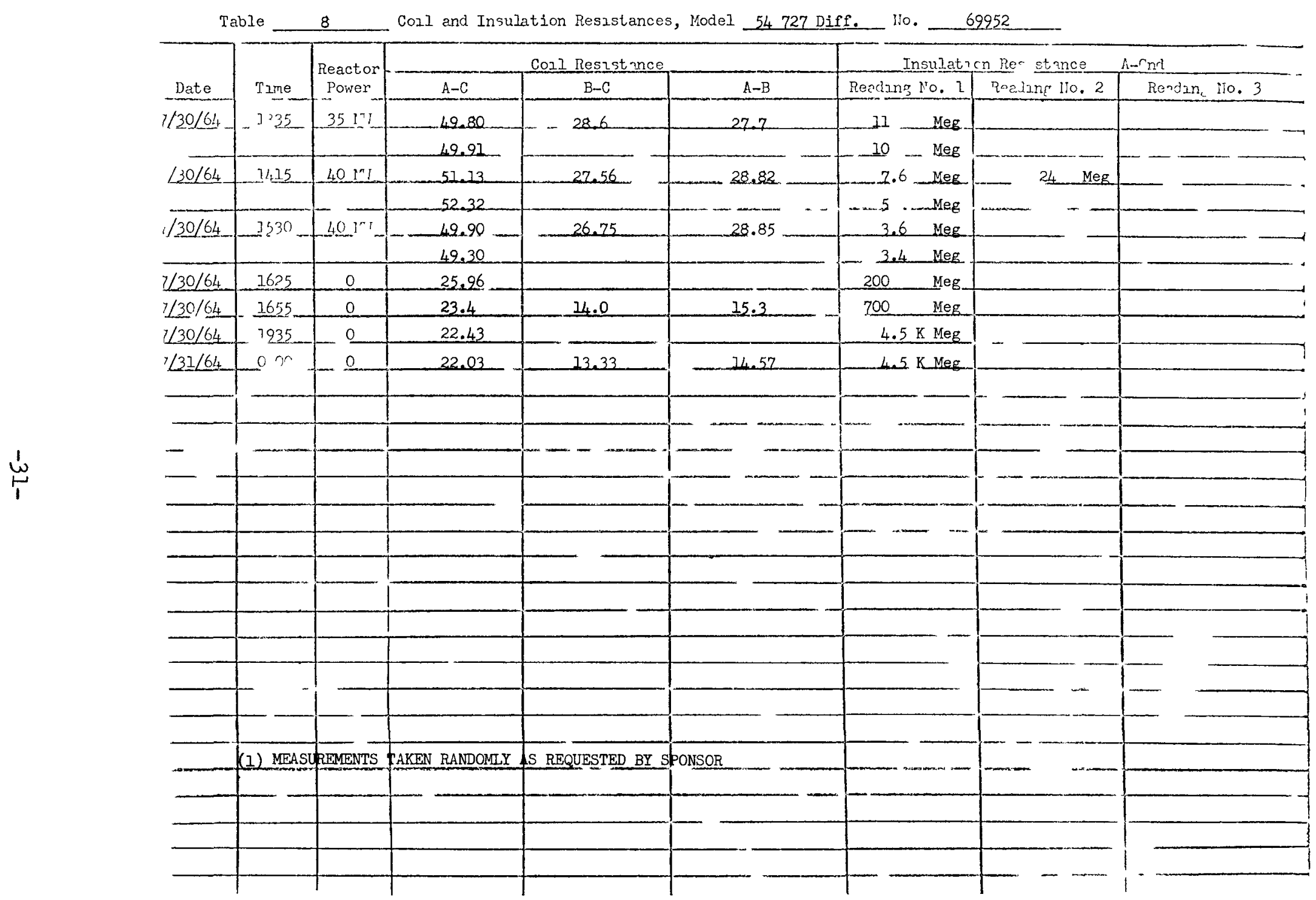




\begin{tabular}{|c|c|c|c|c|c|c|c|c|}
\hline \multirow[b]{2}{*}{ Date } & \multirow[b]{2}{*}{ Time } & \multirow{2}{*}{$\begin{array}{r}\text { React or } \\
\text { Power } \\
\end{array}$} & \multicolumn{3}{|c|}{ Coil Resistance } & \multicolumn{3}{|c|}{ Insulation Resistance $\mathrm{A}-\mathrm{G}$ - } \\
\hline & & & $A-C$ & B-c(i) & $A-B(1)$ & Reading No. 1 & Reading No. $2^{(1)}$ & Reading No. $3^{(1)}$ \\
\hline $7 / 28 / 64$ & 1300 & e & $24.4 I$ & & & $8 \quad \mathrm{KMeg}$ & & \\
\hline $7 / 28 / 64$ & 1350 & 0 & 24.41 & & & $8 \quad \mathrm{~K} \mathrm{Meg}$ & & \\
\hline $7 / 29 / 64$ & 0345 & 0 & 25.16 & & & $2.8 \mathrm{KMeg}$ & & \\
\hline $7 / 29 / 64$ & 114.7 & 0 & 25.60 & & & $2.5 \mathrm{~K} \mathrm{Meg}$ & & \\
\hline $7 / 29 / 64$ & 2035 & 0 & 25.06 & & & $1.6 \mathrm{~K} \mathrm{Meg}$ & & \\
\hline $7 / 29 / 64$ & 2150 & $100 \mathrm{~K} \cdot 1$ & 25.22 & & & $600 \quad \mathrm{Mez}$ & $540 \mathrm{Meg}$ & \\
\hline $7 / 29 / 61$ & 2230 & $1 \mathrm{MI}$ & 26.88 & & & $84 \quad \mathrm{Meg}$ & $84 \quad \mathrm{Meg}$ & $84 \mathrm{Meg}$ \\
\hline $7 / 20 / 64$ & 2350 & I MVI & 27.07 & & & $80 \quad$ Meg & & \\
\hline $7 / 30 / 64$ & 0035 & $5 M$ & 32.95 & & & $15 \quad \mathrm{Meg}$ & $15 \mathrm{Meg}$ & \\
\hline $7 / 30 / 64$ & 0200 & $5 \mathrm{mI}$ & 33.07 & & & $17 \quad \mathrm{Meg}$ & & \\
\hline $7 / 30 / 64$ & 0230 & $10 \mathrm{NIN}$ & 38.72 & & & $9.6 \quad \mathrm{Meg}$ & & \\
\hline $7 / 30 / 61$ & 0350 & $10 \mathrm{mi}$ & 38.22 & & & II Meg & & 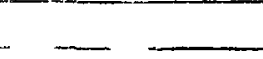 \\
\hline $7 / 30 / 64$ & 0430 & $15 \mathrm{mit}$ & 23.06 & & & 7 . Meg & & \\
\hline $7 / 30 / 64$ & 0600 & $15 \mathrm{MI}$ & 43.14 & & & $6.0 \quad \mathrm{Meg}$ & & \\
\hline $7 / 30 / 64$ & 0625 & $20 \mathrm{MI}$ & 47.91 & & & Lah Meg & & \\
\hline $7 / 30 / 64$ & 0655 & $20 \mathrm{ln} 1$ & 48.30 & & & $40 \mathrm{OMeg}$ & & \\
\hline $2 / 30 / 62$ & 0800 & $20 \mathrm{H}$ & 28.53 & & - & $3,4 \mathrm{Meg}$ & & L_ \\
\hline $7 / 30 / 64$ & 0815 & $20 \mathrm{mi}$ & & & & $+\ldots$ & & \\
\hline $7 / 30 / 64$ & 0842 & $25 \mathrm{MI}$ & 52.82 & & & $2.5 \mathrm{Meg}$ & & \\
\hline & & & 51.80 & & & $2.4 \quad$ Meg & & \\
\hline $7 / 30 / 64$ & 1000 & $25 \because 1$ & 51.81 & & & $2.3 \mathrm{Meg}$ & & \\
\hline & & & 51.46 & - & & $2 \quad$ Meg & & \\
\hline $7 / 30 / 61$. & 3035 & $30 \mathrm{MI}$ & 54.20 & & - & $1.9 \mathrm{Meg}$ & & \\
\hline & & & 51.98 & & & $1.8 \mathrm{Meg}$ & & \\
\hline $7 / 3 c^{1 / 4}$ & 1205 & $30 \mathrm{MI}$ & 48.59 & & $+\ldots$ & $1.65 . \mathrm{Meg}$ & $\ldots$ & - \\
\hline & & & 47.90 & & & $1.6 \quad \mathrm{Meg}$ & & \\
\hline $7 / 30 / 64$ & 1230 & $35 \mathrm{I}^{11}$ & 49.70 & & & $1 \mathrm{LS} \mathrm{Meg}$ & & \\
\hline & & & 44.92 & & & $1.35 \mathrm{Meg}$ & & 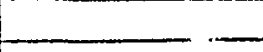 \\
\hline & & & & & & & & 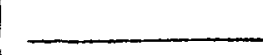 \\
\hline
\end{tabular}


Table ___ Coil and Insulation Resistances, Model 54 726 Abselute No. 70632

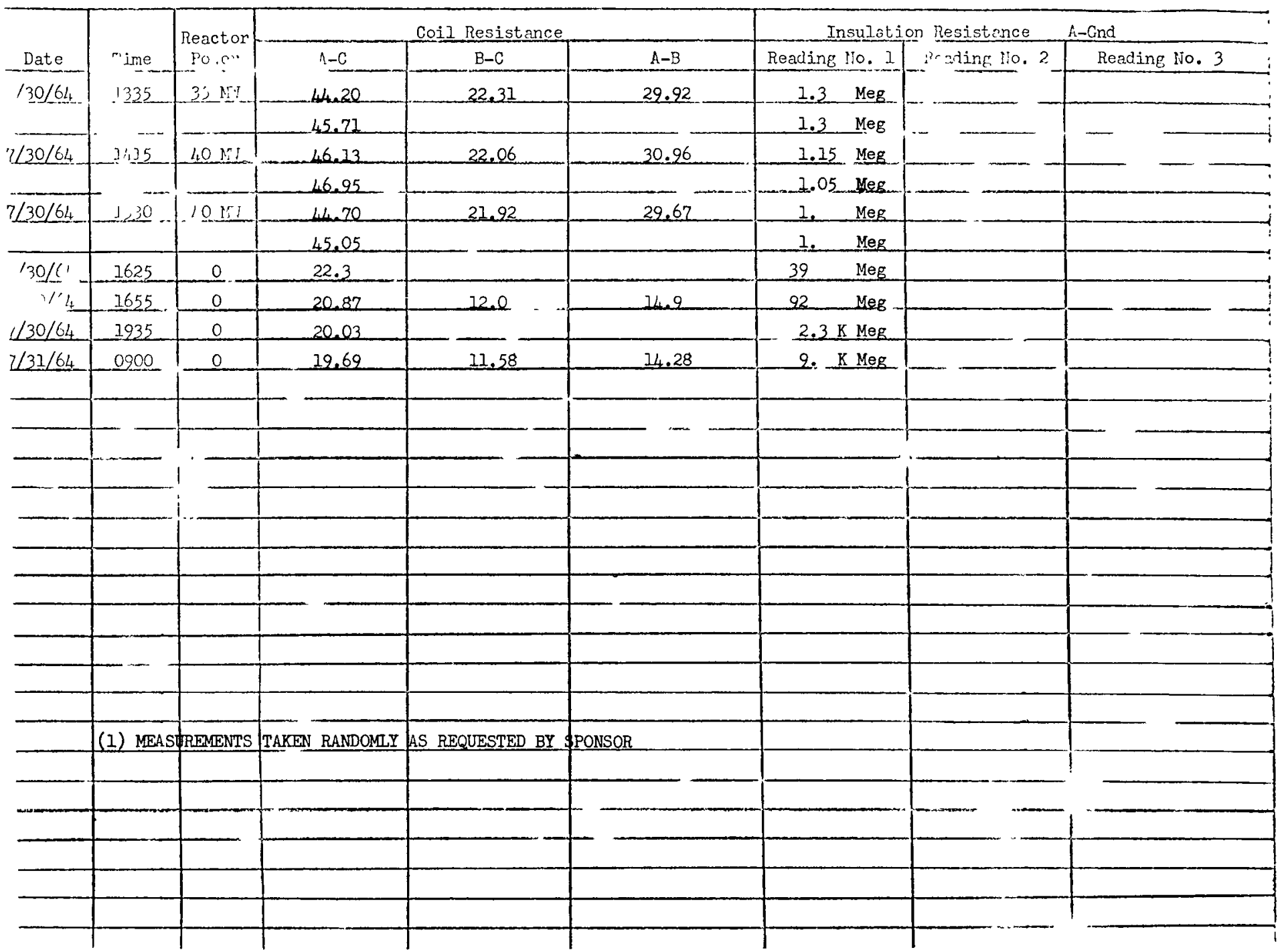




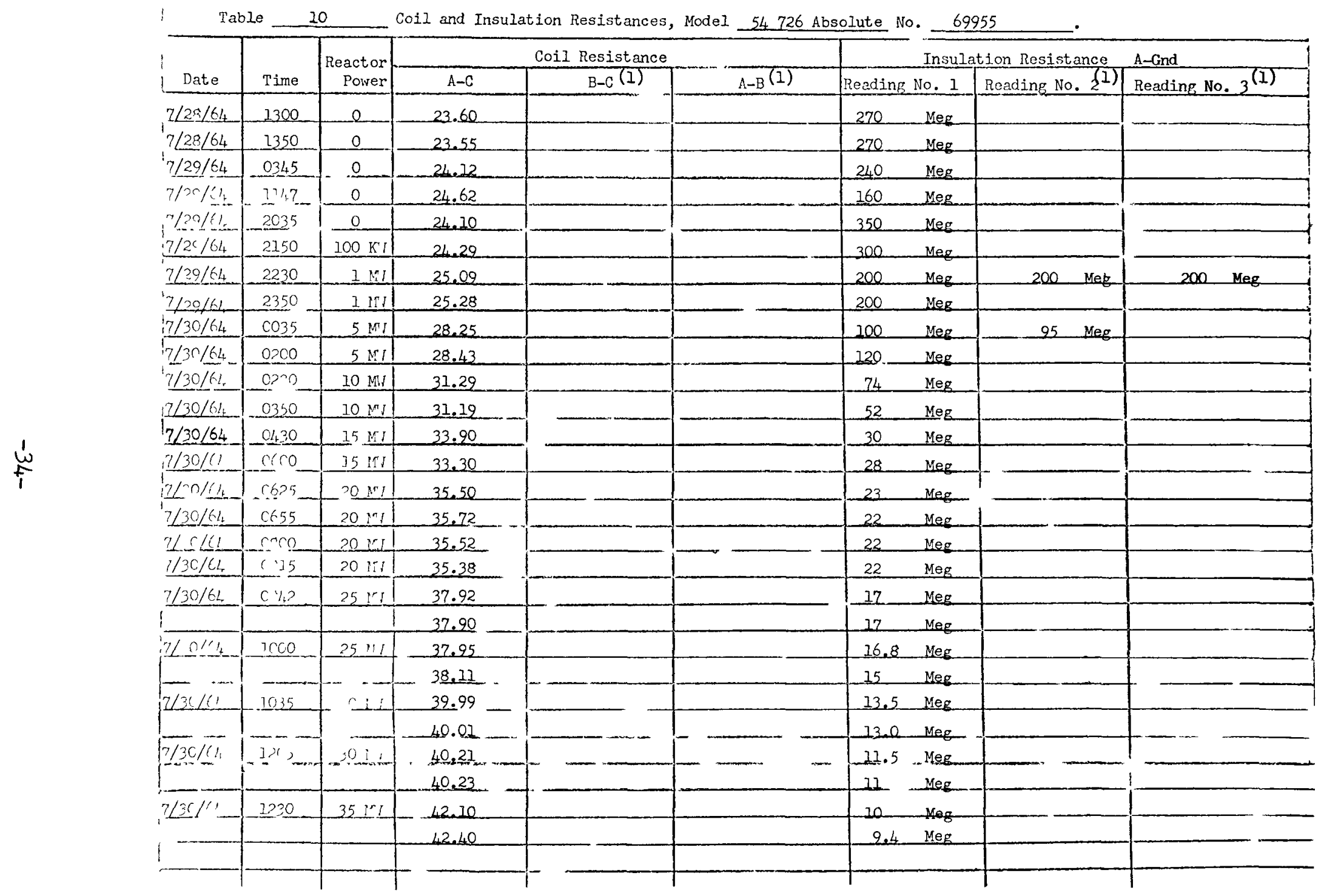


Table $10 \ldots$ Coil and Insulation Resistances, Model 54726 Absolute No. 69955

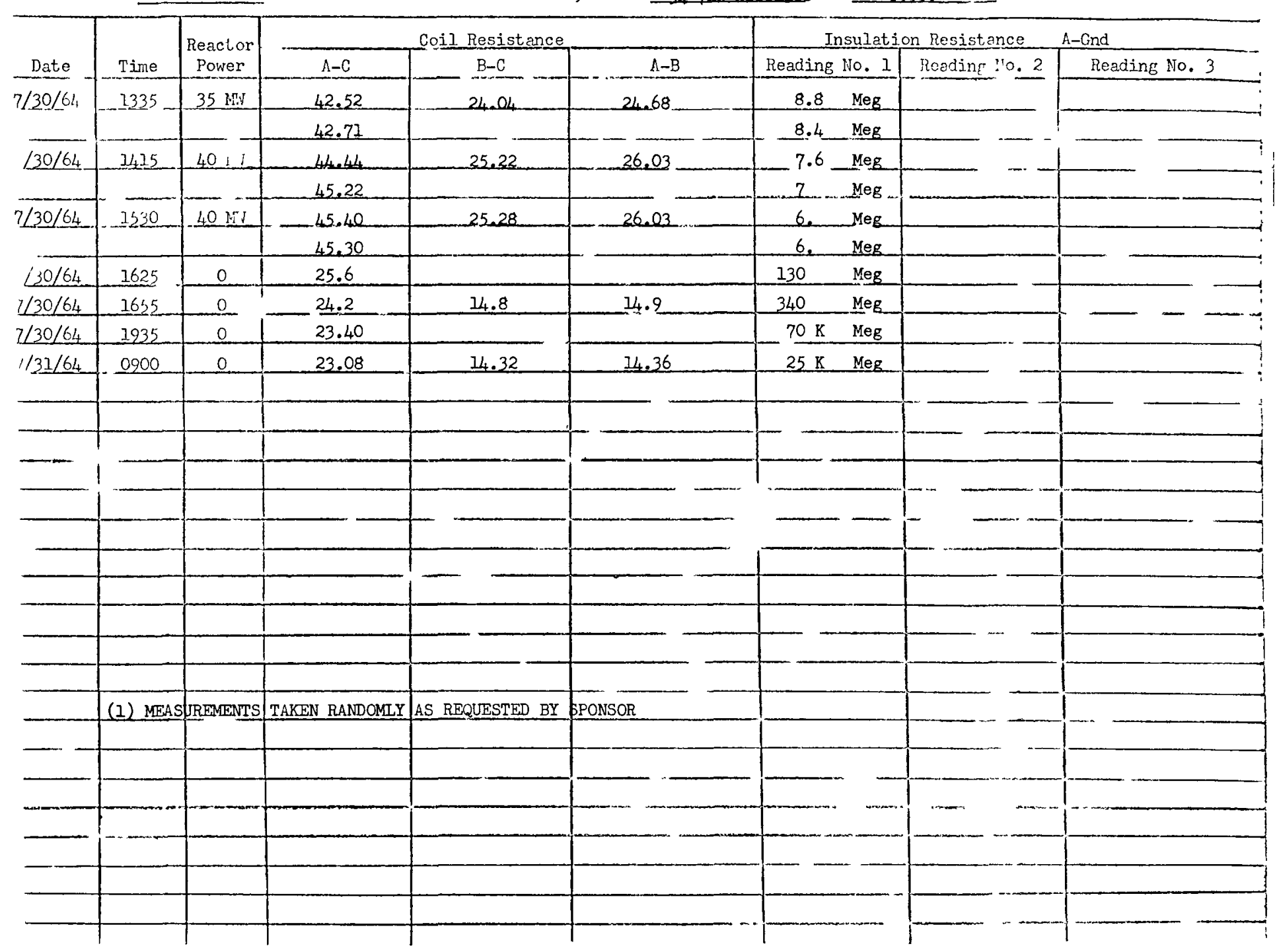




\subsection{REFERENCES}

1. WANI-TNR-119, "Experiment Design Manual and Hazards Analysis, Plum Brook Reactor Facility, Exp. No. 63-05", Westinghouse Astronuclear Laboratory.

2. WANL-REP-2012, "Final Report Design Manual and Hazards Analysis for Experiment No. 23/W506 - Pressure Transducers (RFI, 63-05)", Westinghouse Astronuclear Laboratory.

3. WANL-TME-800, "Final Test Specifications for NRX-A Candidate Pressure Transducers to be Irradiated at the Plum Brook Reactor (23/W506)", Westinghouse Astronuclear Laboratory.

4. WANL-TNR-118, "Operations Manual, Plum Brook Reactor Facility Experiment 63-05", Westinghouse Astronuclear Laboratory. 